University of Louisville

ThinkIR: The University of Louisville's Institutional Repository

Electronic Theses and Dissertations

8-2016

\title{
Let's keep in touch : conversations about access and tactility.
}

Whitney E. B. Mashburn

University of Louisville

Follow this and additional works at: https://ir.library.louisville.edu/etd

Part of the Accessibility Commons, Art Practice Commons, Contemporary Art Commons, Fine Arts Commons, Museum Studies Commons, Special Education and Teaching Commons, and the Theory and Criticism Commons

\section{Recommended Citation}

Mashburn, Whitney E. B., "Let's keep in touch : conversations about access and tactility." (2016). Electronic Theses and Dissertations. Paper 2500.

https://doi.org/10.18297/etd/2500

This Master's Thesis is brought to you for free and open access by ThinkIR: The University of Louisville's Institutional Repository. It has been accepted for inclusion in Electronic Theses and Dissertations by an authorized administrator of ThinkIR: The University of Louisville's Institutional Repository. This title appears here courtesy of the author, who has retained all other copyrights. For more information, please contact thinkir@louisville.edu. 


\title{
LET'S KEEP IN TOUCH: \\ CONVERSATIONS ABOUT ACCESS AND TACTILITY
}

\author{
By \\ Whitney E. B. Mashburn \\ B.A., Vanderbilt University, 2007 \\ M.A., University of Alabama, 2012

\begin{abstract}
A Thesis
Submitted to the Faculty of the

College of Arts and Sciences of the University of Louisville

In Partial Fulfillment of the Requirements

for the Degree of
\end{abstract} \\ Master of Arts \\ In Art and Art History: Critical and Curatorial Studies \\ Department of Fine Arts, Hite Art Institute \\ University of Louisville \\ Louisville, Kentucky
}

August 2016 
Copyright 2016 by Whitney E. B. Mashburn

All rights reserved 

LET'S KEEP IN TOUCH:

CONVERSATIONS ABOUT ACCESS AND TACTILITY

By

Whitney E. B. Mashburn

B.A., Vanderbilt University, 2007

M.A., University of Alabama, 2012

A Thesis Approved on

June 22, 2016

by the following Thesis Committee

\begin{tabular}{c}
\hline $\begin{array}{c}\text { Thesis Director } \\
\text { Peter Morrin }\end{array}$ \\
\hline $\begin{array}{c}\text { Thesis Co-Director } \\
\text { John P. Begley }\end{array}$ \\
\hline Debra Bauder \\
\hline Chris Reitz
\end{tabular}




\section{DEDICATION}

This thesis is dedicated to my family

David Mashburn

and

Ellen Blocker

and

Kent Blocker

and to my dear friends

Bob and Carol Mode 


\section{ACKNOWLEDGEMENTS}

This project would not be nearly as rich or robust without the support of mentors, friends, and family. To Carmen Papalia, the artist without whose collaboration this project would not be possible, thank you. And to my committee, Peter Morrin, John Begley, and Deb Bauder, thank you for your excellent input, enthusiasm for the project, and belief in my abilities. My sincere thanks to everyone who has supported this project and is excited to be part of innovative conversations with me and Carmen: Julie Ault, Debra Bauder, John Begley, Amanda Cachia, Fayen d'Evie, Harrell Fletcher, Kristen Gresh, Micheal Hudson, Mary Jane Jacob, Susan Jarosi, Georgina Kleege, Kristin Lantz, Jen Mergel, Bob Mode, Carol Mode, Peter Morrin, Chris Reitz, Jamie Satcher, and Yasmeen Siddiqui. A special thank you to the teachers and mentors who have encouraged me along my path: Mary Carrithers, Ljubica Popovich, Joanne Rathman, and Fay Renardson, and Jamie Satcher. To Bob and Carol Mode, your constant encouragement is appreciated more than you know. And a very special thanks to my family: David Mashburn, Ellen Blocker, and Kent Blocker. Your support, love, enthusiasm, and willingness to discuss ideas has been invaluable! Thank you for believing in me and for your excitement about this project. By the grace of God go I. Thanks be to God. 


\section{ABSTRACT \\ LET'S KEEP IN TOUCH: \\ CONVERSATIONS ABOUT ACCESS AND TACTILITY}

Whitney E. B. Mashburn

June 22, 2016

Let's Keep in Touch: Conversations about Tactility, a project

collaboratively organized by social practice artist Carmen Papalia and curator Whitney Mashburn, presents conversations between Papalia and artists selected by Mashburn, in regard to tactile access of the chosen artists' works. The project aims to challenge visual biases in museum engagement, through dialogue with living artists.

Carmen Papalia takes social practice in a new direction as he applies it to the topic of accessibility. Using the tool of conversation, he creates strategic infrastructural activism and prompts exploration of non-visual perception.

In this thesis, Papalia's work will be examined and discussed with particular emphasis on the burgeoning field of tactility studies and Papalia's use of conversation within social practice to critique the accessibility of institutions and societal barriers. Additionally, relevant foundations and examples in social practice, institutional critique, and disability studies will be presented. 


\section{TABLE OF CONTENTS}

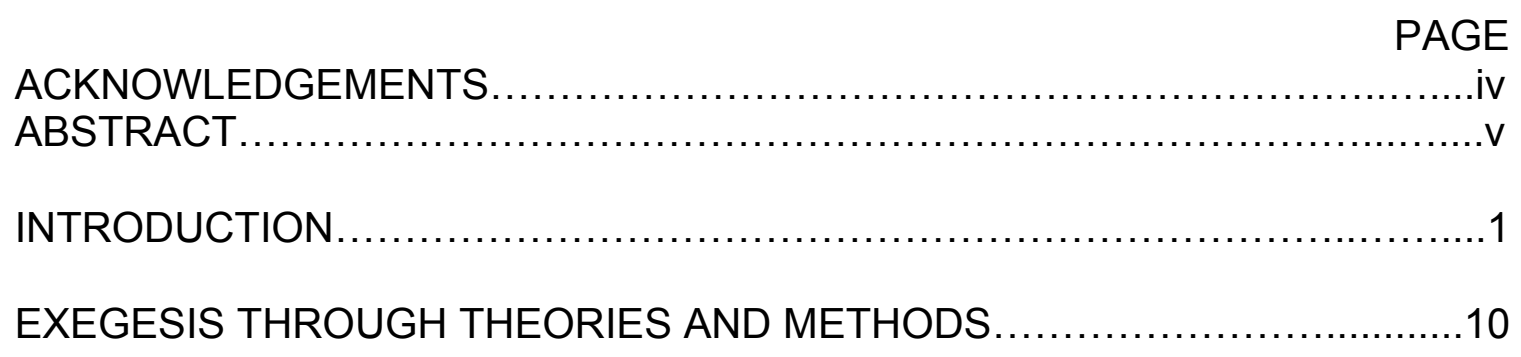

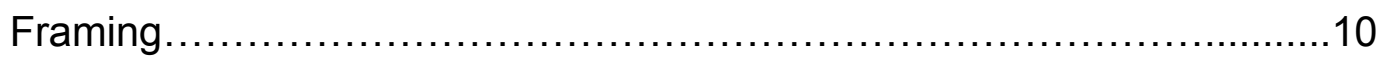

CHAPTER ONE: SOCIALLY ENGAGED ART AND CONVERSATIONS.........12

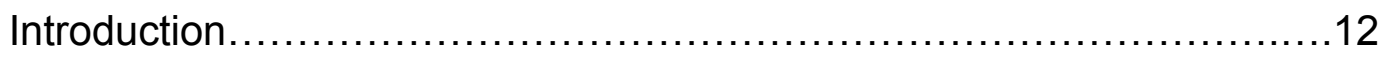

Helguera's Framework for Socially Engaged Art........................13

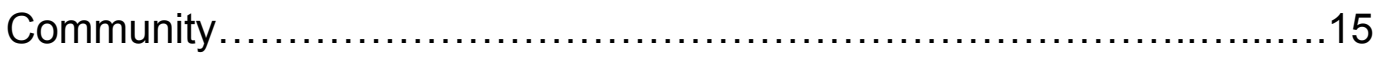

Participatory Art and Building Community.........................17

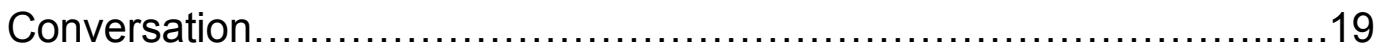

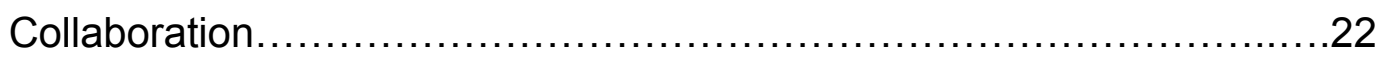

Forms of Collaboration............................................23

Collaboration and Education.....................................24

Theories of aesthetics to consider in application to Papalia's social practice of participatory conversations: relational, social, and dialogical

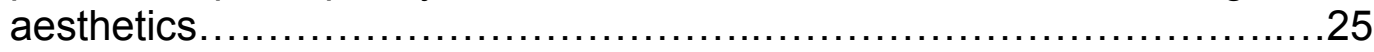

Relational Aesthetics and Conversations.........................26

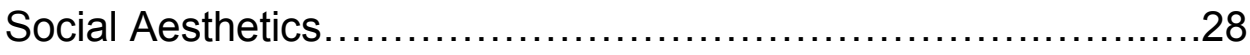

Dialogical Aesthetics................................................... 
Introduction

Inclusive Activism for Accessibility.

Critical Players in Institutional Critique: Implications Regarding Papalia's Practice.

Conceptual collections as institutional critique: Chris Vargas' MOTHA and LKIT.

Street Interventions and Correspondence: Adrian Piper and Carmen Papalia

Operating from Within the Institution: Andrea Frasier's logic and Carmen Papalia. 36

Case Study: The Collective Audit of the Vancouver Art Gallery and the emancipatory stance of Gallery Gachet.

CHAPTER THREE: DISABILITY STUDIES .................................

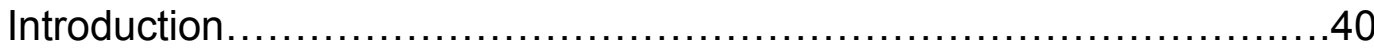

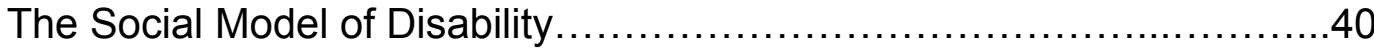

Problematic Attitudes and Language .....................................41

Performing Disability ........................................................

Confluence of disability studies and curating contemporary art............44

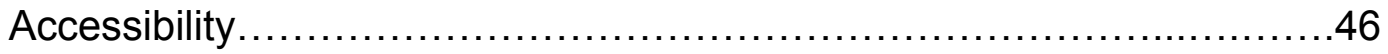

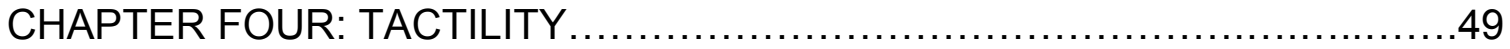

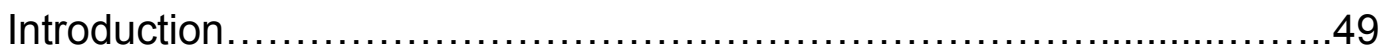

Tactile Engagement: Past Examples..................................50

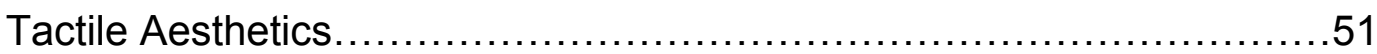

A Methodology for Tactile Aesthetics: Examination Techniques, Properties, and Descriptive Vocabulary.... 
Techniques of Touching ..........................................55

Properties to Evaluate in Tactile Analysis...........................57

Developing a Vocabulary for Haptic Criticism.......................58

From a Scientific Perspective ..........................................59

A Few Thoughts on Museum Engagement..............................62

History of Tactile Engagement in Museums and the Value

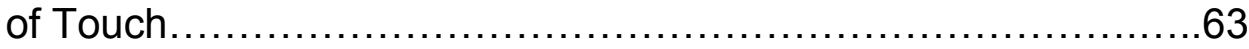

Touch and Control.................................................66

Museum Engagement: A Case Study...........................67

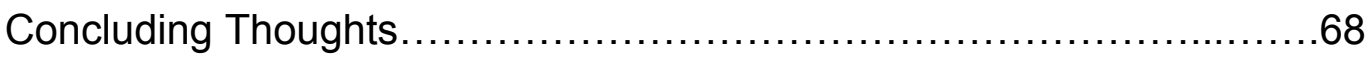

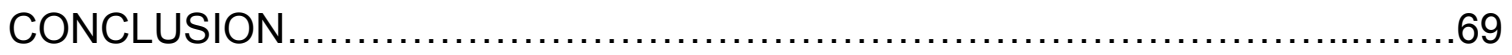

CHAPTER FIVE: COMING BACK AROUND TO LET'S KEEP IN

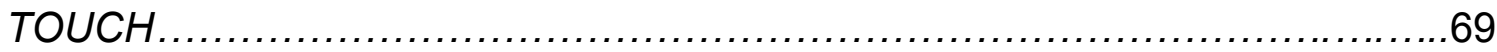

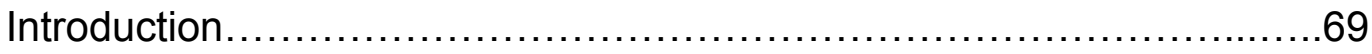

Selected comparative exhibition history of projects involving tactility.......69

Carmen Papalia: Exhibition History and Context...........................73

Mobility Devices............................................... 74

Participatory Interventions Led by the Artist.......................78

Conversations...................................................... 82

Let's Keep in Touch: Future Directions..................................84

Thesis Research and Critical Discourse ..........................84

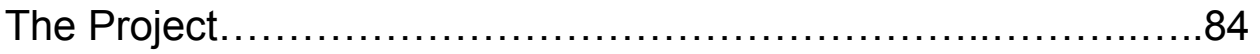

Tactile Access to Two-Dimensional Works: Input from Carol Mode, Painter............................................................ 84

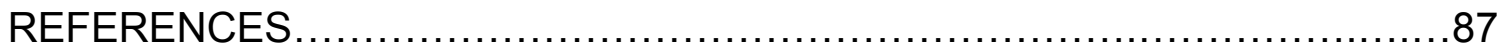




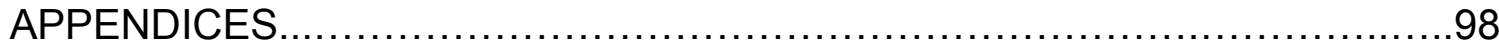

Supplementary Materials for Let's Keep in Touch..........................98

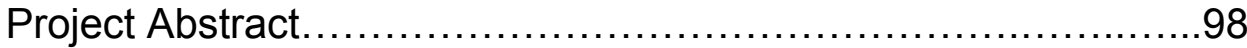

Checklist of Artists ................................................... 99

Papalia's Approach Letter to the Artists..........................101

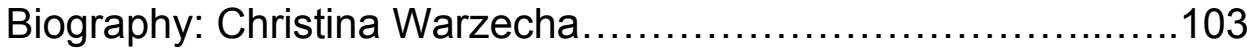

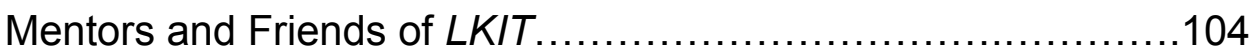

Papalia's Letter to Temporary Services................................105

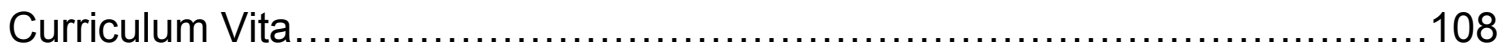




\section{INTRODUCTION}

Let's Keep in Touch grew out of a synthesis, a confluence of ideas after years of thinking, reading, and a myriad of experiences. When I first contacted Carmen Papalia, a Vancouver-based social practice artist, to gauge his interest in working with me on my thesis project, his response was wonderfully open and curious to learn more. We proceeded to share ideas and thoughts that we had been processing in regard to each of our respective practices, and found we shared ardency for, among other things, prodding multi-sensory experiencing of art, improving accessibility, and of supporting the social model of disability. After a series of phone conversations and emails with flowing give-and-take stream of consciousness brainstorming, we arrived at a project concept proposed by Carmen, and I found a professional friendship developing as well. But that's just it, that is how Carmen works with others - through relationship building. It is inherent in his candid, transparent manner of discussion, his gracious encouragement of and regard for others, and his genuine, contagious enthusiasm for sharing ideas and building community. He does not call those he works with by the lofty term "colleagues," he calls them friends. Why? Because he esteems them as friends, and treats them with a certain measure of care and respect that is often unheard of in professional dealings. During one of our

phone conversations, I mentioned this observation to Carmen and he noted that 
these interactions with others make him feel more connected with the world around him. Upon processing this thought further, he arrived at the title of our exhibition, Let's Keep in Touch, a nod not only to our focus on tactility, but also to his building of community and relationships through candid conversations and kindly astute discussions.

In keeping with the project's deliberate focus on dialogue and storytelling, this thesis will follow in a conversational narrative, with discussion of theories and methods as applicable to the exhibition project, its underpinnings and ramifications. But first, a bit of background: I present a description of the project itself to serve as a reference point for further critical discourse.

Let's Keep in Touch, in its current state, is the second of two proposals. The first concept that was discussed involved loans from Louisville's Speed Art Museum. These selected loans would have been exhibited in a separate space in Louisville, presumably in the Schneider Hall galleries at the University, where they would have been made available with tactile access. Here, Carmen was clear in his desire to use art objects from the permanent collection which were of exhibition quality, and not to use objects which might have been reassigned to educational purposes because of their abundance or damaged condition. Though his proposal was a tall ask, it was successful in its very nature of questioning the "white cube" and our expected "hands off" protocol for experiencing art.

It challenged me as a curator as well. I extolled the virtues of the proposal and the "touchy" questions it raised, I relished the subversive nature of it all, and I 
felt it was quite a timely issue to investigate though practice. But at the same time, I admit, a few things made me nervous as well: the timing of arranging loans in just a few short months, the question of whether the Speed folks would be on board with tactile access during a moment of great activity within the institution, and the conservation concerns which would certainly be involved. But isn't this the essence of the contemporary curatorial experience? To work with an artist who questions past studio and museum practice and forces you to take up difficult questions and make strides for expanding our experience of art, indeed it is exhilarating and a worthwhile task.

In the end, though the curatorial response from the Speed was kind and supportive, the timeframe was quite impossible, due to the grand reopening of the museum, imminently approaching in March. We also considered the Filson Historical Society, but as it too was under major renovation, most items were in storage for a reopening scheduled for the fall. A similar story was true for the Kentucky Museum of Art and Craft reopening in June. Truly, Louisville's art scene is growing, as evidenced by the expansions and improvements of these three institutions alone.

Encouraged by the input gathered from local institutional staff, mentors, and friends, we moved forward to craft a new plan that still addressed the issues of tactility and visitor engagement in museum spaces. I went back to Carmen with information gathered from my mentors. We discussed the role of public art, as suggested by John Begley and Peter Morrin, the loophole of living artists granting certain conditions (like tactile access) for their works in institutions as 
mentioned by Jen Mergel, and the possibility of working with the American Printing House for the Blind (APHB), based in Louisville. Carmen, remembering a chat he had while hiking with Julie Ault on a retreat while in graduate school, and drawing upon his discussions with Georgina Kleege about tactility, listened to all of my sharing as well. He thoughtfully responded with a suggestion that has become the basis of our current project, which quite simply is the following. I will choose a set of artists which, curatorially, form a coherent grouping. Carmen will then contact each of these artists to talk to them about granting tactile access to their work(s) in whichever institution houses their work(s). He will request a stipulation be added to the respective collections object file that allows visitors tactile access, via consent given directly by the artist. This process somewhat simplifies negotiations with institutions regarding access to an object, for inherently the decision of the artist is the final word on the matter. Also, no loans are involved for this first iteration of our project, which has a tighter timeline for my thesis. The simplicity of the plan allows for a greater focus on the conversations between Carmen and the respective artists, which ultimately forms the documentation for our exhibition. In this way, we have come back full circle to dialogical aesthetics, and Carmen's use of conversation in his practice of socially engaged art.

The plans for the exhibition include elements which together aim to stimulate visitors to think broadly about different ways to experience art, give them a personal view into the conversations between Carmen and other artists discussing how works are treated in an exhibition space, and to allow physical 
access to and manipulation of a singular ceramic installation piece by Christina Warzecha which was created for this project. First of all, the exhibition will present documentation of the project process. Mainly, the documentation will include excerpts of the 'tactility conversations' between Carmen and the selected artists. These passages will be made available via text, but in keeping with the aim of facilitating non-visual learning, each of the excerpts will also be made available in audio format, with recordings of the text being read aloud by Carmen, me, and other supporters of the project. The goal in using our voices instead of a screen reader is to help the visitors feel more integrated in the dialogical process. Also as a part of this process, we would like to gather feedback from tactile interactions: both for visitors experiencing Christina's piece in our exhibition, and for visitors who touch the chosen works in their respective home institutions. In our exhibition, we will give visitors the opportunity to record their responses via voice recorders, and to listen to others' responses as well. In the home institutions of the chosen works, the aim is to gather descriptive phrases and adjectives after haptic interaction with the given works in order to add this information to the museum object file. As museum object files are usually visually focused, the addition of tactile-based descriptors will challenge the visual hegemony and offer a more comprehensive explication of the art object. This step supports Carmen's desire for promoting long-term, lasting institutional changes.

Other segments of documentation in our exhibition will highlight interactions between Carmen and Christina Warzecha, the sculptural ceramic 
artist behind the installation piece made for this show. Carmen has plans to visit Christina in her Chicago-area studio, to talk about their respective practices and the intersections thereof, to take her on an eyes closed walk, discuss the project, and to document this entire process with the assistance of his partner, Kristin Lantz.

The final piece of the exhibition will be the ceramic work by Christina. It will be modular, sculptural, and able to be manipulated by visitors. Early discussions regarding the work hinted that the installation might incorporate both wall and floor space. Christina's work lends itself to the investigation of texture, process, and material, so I feel that it will function well for visitors to explore while thinking about the experience of tactile access to art.

In this iteration of Let's Keep in Touch, the selected artists with whom Carmen will communicate are a range of individuals whose works are sculptural and/or textile-based. They represent all stages of career, and are not limited to a single geographic locale. The unifying criteria for choosing them was that their work embodied an interesting tactile aesthetic, specifically of form and texture. From reading literature by Georgina Kleege and documentation of other tactile investigations, from listening to Carmen's opinions and thoughts, and from taking in non-visual observations during an eyes-closed walk with Carmen this spring, I did my best to understand what a successful tactile aesthetic might be. Using this as my criterion, I sought out works which I thought might be fascinating to explore not visually, but rather by touch. The authors of these works form my list of artists curated for Carmen's dialogical process. Hence, through this project, 
we present a new way of curating, a new way of experiencing art, a 'new way of seeing:' not by looking with the eyes, but by touching with the hands (or elbows, or knees, for that matter!).

Another component in my curatorial decision-making process is that Carmen had suggested that these works be the beginning of a virtual collection, the start of a virtual museum collection all its own, with the unifying factor being that of tactile aesthetic. In this way, I wanted my selections to be diverse enough to counter the current hegemony of the canon, not just in the realm of visual vs. tactile, but also in that the contributing artists might offer up an array of perspectives to further enrich our collection. Each of the artists are tackling completely different topics through their work. This both enhances the body of the collection, and it differs from a common curatorial approach of thematically grouping artists by the topics they are investigating in their work.

In thinking broadly about forming a collection, media comes into play as well. This iteration of the project, presented at the University of Louisville in summer 2016, will encompass only works that are sculpture and/or textile-based. Future instances of the project, and Carmen and I do plan for this to be a longrange project, will take up works in other media. My proposal for such is to address sculptural relief and subtly textured prints and paintings in the second round, and then thirdly investigate photographs and sound waves (as in an audio piece). In this way, the collection would, piece by piece, amass works in a progression from gross to fine detailing in form and texture, with a perceived developing awareness of tactile aesthetic. We can use what we have learned 
from the feedback in each prior engagement to select the next round of objects and artists.

One last framing that I used in curatorial choices for $L K I T$ is that of the project as experiment. The range of artists includes those who are in various stages of their career (early, mid, and late), hail from six continents, and are interested in investigating a variety of issues in their respective practices. Inherently, I realized

I chose ten women and six men; with full disclosure, I feel my interest in feminist studies has a bit of responsible underlying influence. My aim in choosing artists of varying ages, perspectives, and topical foci is to have a diverse 'sample' (to use the jargon of the scientific method). I felt like this 'sample' might give us a better understanding of artist opinions on tactile access than if we were to have asked only artists of one career stage or geographic locale or who were all investigating a single subject in their work. This discussion brings us back around to realize again the single unifying factor for the curatorial choices: that of showing potential for a tactile aesthetic in form and texture.

Envisage the layers that, together, make up the project and exhibition of Let's Keep in Touch. Primary is the layer of Carmen's socially engaged art: his correspondence with artists, conversations about tactility, and institutional interventions. Secondly, there is the conceptualized collection, the curatorial grouping of works chosen for their physical texture and form as interpreted through touch. The third layer is the haptic presentation of the entire process in an exhibition format that reflects the awareness of multisensorial engagement in 
a 'white cube' setting, which brings us to an integrated fourth layer. Here is Christina Warzecha's installed modular sculptural ceramic art work, commissioned for this very project, and made in conjunction with input from Carmen. It is specifically tactile, providing direct engagement with the audience, through a focus on process and material. Finally, we must consider the curatorial and theoretical framing of it all together, as a cohesive and dynamic project in exhibition-making. Together, all of these layers comprise the multifaceted Let's Keep in Touch project, and will be will be examined through exegesis of their underpinnings and parallels in theories and methods over the next chapters.

Throughout this analysis, however, a consistent yet dynamic thesis remains as a unifying thread. Carmen Papalia takes socially engaged art in a new direction through his engagement with museums and individuals regarding accessibility, using his chosen tool of conversation and collaboration. His work draws from the discourses of social practice, institutional critique, disability studies, and tactile aesthetics to tackle the topic of accessibility and to question how we experience art: by engaging in a playfully subversive yet inquisitive and constructive dialogue to sensitize, reframe, and broaden our manner of 'seeing' and experiencing art and our surrounding environment. He thus uses the social tool of conversation to challenge institutional accessibility and prompt exploration of non-visual perception. 


\section{EXEGESIS THROUGH THEORIES AND METHODS}

\section{Framing}

Carmen Papalia describes his practice as "institutional critique and strategic infrastructural activism toward a liberatory social system that allows for wellness, agency and thriving for those who face barriers as the result of disabling social and cultural conditions."1

Papalia's practice is primarily rooted in socially engaged art, which is, as Pablo Helguera describes it, referential of other disciplines to inform itself. ${ }^{2}$ Depending on the individual artist, one's respective practice within socially engaged art-making is informed by a relevant combination of other fields, in a truly multidisciplinary approach. Therefore, this thesis will begin with a framework of socially engaged practice, and then move to a cursory yet deliberate look at other critical discourses (institutional critique, disability studies and related theories) which enrich Papalia's social practice as he promotes accessibility and non-visual engagement. Interwoven will be a focus on Papalia's use of dialogue within socially engaged art to tackle tactility and multi-sensorial learning and experiencing of art. As this project has a particular emphasis on haptics, after the paper's consideration of institutional critique and disability

\footnotetext{
${ }^{1}$ Papalia, Carmen. "Re: Thesis." E-mail to Whitney Mashburn. March 31, 2016.

2 Helguera, Pablo. Education for Socially Engaged Art: A Materials and Techniques Handbook. New York: Jorge Pinto Books, 2011.
} 
studies, there will be a focused discussion of tactility: recent scholarship from arts and sciences, insights from Georgina Kleege, and a proposed structure for critical analysis of tactile aesthetics. The concluding chapter will summarize Papalia's exhibition history and give further details of this project, present other recent and relevant exhibitions about non-visual experiencing of art objects, and discuss future directions for Let's Keep in Touch and its accompanying research and exhibition prospects. All of these topics will enrich the understanding of Papalia's conversations about access and tactility. 


\section{CHAPTER ONE: SOCIALLY ENGAGED ART AND CONVERSATIONS}

\section{Introduction}

Social practice aims to take art outside of its traditional space, and create lasting social changes through activism and community engagement. As a starting point, Papalia's approach may be considered within the lens of Helguera's seminal yet approachable text on the subject, Education for Socially Engaged Art. $^{3}$ This chapter's discussion will highlight aspects of community, conversation, and collaboration in Papalia's practice. In light of Papalia's conversational strategies, ideological connections to the theories of relational, dialogical, and social aesthetics will be analyzed as well.

Social practice, which is within the realm of, and can be considered the latest iteration of, socially engaged art, is a relatively new phenomenon of the last twenty years, more intensely of the last ten. It seems at times quite an allencompassing term, a "catch-all," for labeling "a variety of 'post-studio' practices in contemporary visual art as well as the 'post-dramatic' practices of contemporary theatre. ${ }^{4}$ At times, it envelops aspects of social dialogue,

\footnotetext{
${ }^{3}$ Helguera, Education for Socially Engaged art. Helguera spent time in residency with Harrell Fletcher's social practice MFA program at Portland State University, where Carmen studied for graduate school. It is with full disclosure that I use Helguera's text as the primary one to examine Carmen's work, as I see many connections between Carmen's practice and Helguera's framing. ${ }^{4}$ Jackson, Shannon. "Performance, Aesthetics, and Support." in Jackson, Shannon, ed. Social Works: Performing Art, Supporting Publics. New York: Routledge, 2011, 13.
} 
grassroots efforts to effect local change, political stances to edit policy, and/or performative qualities. The number of amassed projects conducted under the 'social practice' heading over recent years is incalculable. It is curiously related as a democratized, younger generation to Nicolas Bourriaud's relational aesthetics, and could be argued as a successor to Soviet social realism, characteristics of the Weather Underground and Kathe Kollewitz, and even the social realism of Courbet. It is important to jointly recognize its far-reaching aims and effects of social and community engagement, and its unwieldiness under traditional institutional standards.

Social practice has seen itself manifested through conferences such as Open Engagement (begun in 2007), projects ${ }^{5}$ such as Mary Jane Jacob's early example Culture in Action (1995) ${ }^{6}$, and groundbreaking academic programs such as the MFA in social practice at Portland State University, begun by Harrell

\footnotetext{
${ }^{5}$ Claire Bishop notes that the term 'project' first came into vogue in the early 1990s, around the time of Culture in Action, to cope with the complexities of participatory art not fitting the mold for traditional exhibition formatting. Bishop, Claire. Artificial Hells: Participatory Art and the Politics of Spectatorship. London: Verso Books, 2012, 205.

${ }^{6}$ Social practice has developed out of a number of regional centres (Claire Bishop notes the difference in approach to participatory social works, citing the 'relationality' of the French and the 'criticality' of the North Americans and Germans. Project Unité (1993) was one of the last instances of both camps working in the same project.), two of which in the US have been most influential on Papalia's work: Chicago, IL and Portland, OR. Carmen completed his graduate studies in the recently formed Art and Social Practice MFA program at Portland State University in 2012. During which time, the program was co-directed by founder Harrell Fletcher and Jen Delos Reyes, of each of whose practice he became closely aware. Earlier, in Chicago, the urban community-based activism led by Mary Jane Jacob created projects like Culture in Action. Additionally, interventions and outreach of the afore-mentioned Temporary Services infused the midwestern hub through many small gestures. Group Material, though based in NYC, is worth noting, in that Papalia's work, and this project in particular, has been influenced by his conversations with Julie Ault. Her commitment to the political activism and relevance of artmaking is evident in Papalia's practice as well. For further reading: Green, Alison. "Citizen Artists: Group Material." Afterall • Journal • Issue 26. Spring 2011. http://www.afterall.org/journal/issue.26/citizen-artists-group-material.
} 
Fletcher in 2007. ${ }^{7}$ A recent New York Times article describes the advent of social practice into more of a mainstream consciousness, citing Papalia as its titular example of the emerging generation of critical thinkers and activists. ${ }^{8}$ For now, let us look to Helguera's framing for a general understanding of social practice and its main components.

\section{Helguera's framework for socially engaged art}

Helguera presents two main requirements of socially engaged art, that it "depends on actual -- not imagined or hypothetical -- social action," and that that action is also a "symbolic statement in the context of our cultural history (and/or art history) and enter[s] into a larger artistic debate."

Socially engaged art "falls within the tradition of conceptual process art," is influenced by performance art and installation art, and is characterized by "its dependence on social intercourse as a factor of its existence." ${ }^{\text {10 }}$ Most importantly, and most pertinent for Papalia's practice, it draws from other fields to highlight issues and bring awareness to a subject, questioning assumptions and promoting lasting changes. Helguera writes, "it is this temporary snatching away

\footnotetext{
${ }^{7}$ Fletcher, Harrell. "4.26.16." Harrell Fletcher. April 26, 2016. http://www.harrellfletcher.com/?cat=33. In this post, Fletcher writes about his thoughts in formulating the social practice program at PSU.

${ }^{8}$ Grant, Daniel. "Social Practice Degrees Take Art to a Communal Level." The New York Times. February 06, 2016. http://www.nytimes.com/2016/02/07/education/edlife/social-practice-degreestake-art-to-a-communal-level.html? r=0.

${ }^{9}$ Helguera, Education for SEA, 8 and 36.

${ }^{10}$ Helguera, Education for SEA, 2-3. Here, Helguera goes on to say that "in previous decades, art based on social interaction has been identified as 'relational aesthetics' and 'community,' 'collaborative,' 'participatory,' 'dialogic,' and 'public' art, among many other titles. (Its redefinitions like that of other kinds of art, have stemmed from the urge to draw lines between generations and unload historical baggage.) 'Social practice' has emerged...most...recently...and is the most generally favored term for socially engaged art."
} 
of subjects into the realm of art-making that brings new insights to a particular problem or condition and in turn makes it visible to other disciplines." ${ }^{11}$ Papalia draws from the awareness of being a non-visual learner, or as others might describe it, the barriers encountered with having a visual impairment. He allows his art-making to be strategically influenced by these experiences and thereby shares his explorations with the public, critiques institutions, and opens awareness to multisensorial engagement in order to promote lasting changes in museum policy and how individuals "see" the environments around them.

Helguera provides a clear synopsis of socially engaged art, or SEA as he refers to it, defining what it is and what it is not, and discussing its elements: community, situations, conversation, collaboration, antagonism, performance, documentation, transpedagogy, and deskilling. ${ }^{12}$ All of these components strongly apply to Papalia's practice. However, for the purpose of this analysis, let us focus on the overlapping yet most relevant aspects of community, conversation, and collaboration. For to truly understand Papalia's approach, we must assess his use of conversation in the context of dialogical practices and collaboration, as his main tool of socially engaged art-making.

The next section will use Helguera's outlining of social practice as a framework (specifically the components of community building, conversation, and collaboration), and will show how Papalia's practice is situated in SEA and takes it into new directions in its adoption of institutional critique and accessibility

\footnotetext{
${ }^{11}$ Helguera, Education for SEA, 5.

12 Helguerra Education for SEA, 5.
} 
activism. As relevant, other examples in practice and critical dialogues will interweave into this discussion.

\section{Community}

Through the tools of participation, conversation, and performance, Papalia challenges perceptions and assumptions about access and builds a community of solidarity. Carmen Papalia's art is that of building community. In thinking of the community engaged by SEA, Helguera references Jacques Rancière's phrase "a community of narrators and translators," meaning that the community reached by SEA is "emancipated," having "willingly engage[d] in a dialogue from which they extract enough critical and experiential wealth to walk away feeling enriched, perhaps even claiming some ownership of the experience or ability to reproduce it with others." ${ }^{13}$ Such is the case in Papalia's eyes-closed walks, officially called the Blind Field Shuttle (2012-present), and his eyes-closed museum tours, such as The Touchy Subject $(2014)^{14}$ at the Guggenheim and See for Yourself $(2013)^{15}$ at the Whitney Museum of American Art, and his EarCleaning Tour (2013) at MOMA. ${ }^{16}$ The common thread throughout all of these experiences is that the participants (the engaged community) engage in

\footnotetext{
${ }^{13}$ Rancière, Jacques. The Emancipated Spectator (London: Verso, 2009), p.22, in Helguera, "Education for SEA," 13.

${ }^{14}$ Krantz, Georgia. "How Do You See a Museum with Your Eyes Closed?" Guggenheim. April 29, 2014. https://www.guggenheim.org/blogs/checklist/how-do-you-see-a-museum-with-your-eyesclosed. For further information about each of these interventions, please see the annotated exhibition history in chapter five.

15 "Carmen Papalia, See for Yourself." Whitney Museum of American Art. June 7, 2013. http://whitney.org/Events/SeeForYourself.

16 "Arts Initiative Columbia University Experience, Engage, Create." Artist Workshop: EarCleaning Tour with Carmen Papalia. November 15, 2013.

http://artsinitiative.columbia.edu/events/artist-workshop-ear-cleaning-tour-carmen-papalia.
} 
Papalia's planned activity of closing one's eyes and carefully listening, whether it be to environmental sounds or to a museum staff person's descriptions. Through the practice and focused experience of shutting off visual perceptions and opening one's sensitivity to non-visual observations, the participants are immersed in an activity which they can replicate in other environments on their own and share with others, epitomizing Rancière's concept of a "community of narrators and translators." ${ }^{17}$

Community also raises the questions of audience. Who is the engaged audience? What may we assume about audience competence? For the LKIT project, there are layers of audiences and communities involved. Helguera notes, "we build because audiences exist. We build because we seek to reach out to others, and they will come initially because they recognize themselves in what we have built...they are not static spaces for static viewers but everevolving, growing, or decaying communities." ${ }^{18}$ Papalia, in his use of conversation and reaching out to others, helps build these communities through the process of his projects. His community is the public, anyone who is nearby or invited to an intervention of his and chooses to participate, whether the activity is a museum tour, an eyes-closed walk, or a conversation. ${ }^{19}$ He starts with eliciting the curiosity of potential participants, then engages them in the activity of his work, in which their active participation is vital. Coming out of the experience, each of the individuals has been challenged to rethink their perceptions and

\footnotetext{
${ }^{17}$ Rancière, Jacques. The Emancipated Spectator. London: Verso, 2009, 22.

${ }_{18}^{18}$ Helguera, Education for SEA, 22.

${ }^{19}$ For a description of Papalia's projects and to better understand his process, please see the annotated exhibition history in chapter five.
} 
assumptions about accessibility and non-visual engagement. His communities consist of everyone affected by his interventions and conversations, be it museum staff, visitors and local residents, other artists, and curators -- anyone who becomes an active participant in his work.

But there are always assumptions to be made about audience competence. The beauty of Carmen's work is that, though it is conceptually complex, it also functions at a level of simply questioning and sensitizing sensory perceptions, in this case, tactility. As Yi-Fu Tuan explains regarding touch, it is "a delicate instrument for exploring and appreciating the world," and although "training, naturally, increases sensitivity," "most of us have...skill even without training." ${ }^{20}$ In other words, basic thinking about our tactile sensory input is something that does not require much in the way of training or specialization. Thus, Papalia's projects function for all levels of audience competence, from the novice to the intellectual.

Through the process of actively soliciting the engagement of others in his interventions and conversations, Papalia builds community as he shares new ideas about perception and accessibility.

\section{Participatory art and building community ${ }^{21}$}

\footnotetext{
${ }^{20}$ Tuan, Yi-Fu. "Pleasures of Touch," in Classen, Constance, ed. The Book of Touch, Oxford: Berg, 2005, 76.

${ }^{21}$ Another point of Helguera's comes into play here, which is time and effort invested into community. In order for a SEA project to see lasting effects and show genuine interest in its involved community, the artist must invest time and effort immersing him or herself in the community. I see this manifested in Papalia's work in two ways: first, that he has been immersing himself in the community of contemporary artists since graduate school (with contemporary artists being one of the communities involved in LKIT); and secondly, that he is committing time and
} 
Continuing the discussion of community, it is important to consider Papalia's work as participatory art. ${ }^{22}$ But one may not speak of his work as participatory without also noting its inclusiveness. Group Material referenced bell hooks in writing about their Democracy project of 1990, "we must focus on a policy of inclusion so as not to mirror oppressive structures." ${ }^{23}$ Carmen is inclusive to everyone who is willing to participate with him in the explorations which form his projects. In fact, perhaps his work is best described as collaborative explorations which challenge oppressive barriers to accessibility.

What types of participation does Papalia utilize in his projects? Helguera outlines four variations in layered participatory structures. ${ }^{24}$ In analyzing Papalia's work under Helguera's categories, most of his above-described performance pieces move past nominal participation to involve directed participation and creative participation, meaning that the visitors "complete a simple task to contribute to the creation of the work" and "provide content for a component of the work within a structure established by the artist." ${ }^{25} \ln L K I T$, however, I see Papalia using the fourth and most involved layer, which is

effort over a period of years (having thought about this project for a number of years and planning for it to continue over the next few years).

${ }^{22}$ Additionally, Claire Bishop, in Artificial Hells, notes the difficulties and paradoxical nature of exhibiting and documenting participatory SEA and the complexities of its projects. In our project alone, Carmen has spoken to me extensively about wanting the viewers to the exhibition to feel a part of the project, to understand the layers of it, and to be immersed in the multisensorial access via the exhibition. We also plan to set up a web presence, to have a project summary, to document responses to Warzecha's piece, and to share the conversations between Carmen and the selected artists (in both audio and written formats). We aim for our audience/participants to understand the complexities of the project and to feel immersed in contributing their thoughts, with facilitated access available. Bishop, Claire. Artificial Hells: Participatory Art and the Politics of Spectatorship.

${ }^{23}$ Here, Group Material was paraphrasing bell hooks. Group Material (Doug Ashford, Julie Ault, and Felix Gonzalez-Torres). "On Democracy." In Participation, edited by Claire Bishop, 135-37. London: Whitechapel, 2006.

${ }^{24}$ These four variations are: nominal, directed, creative, and collaborative participation.

${ }^{25}$ Helguera, Education for SEA, 15. 
collaborative participation. Here, Carmen engages directly with the other selected artists in conversation about tactile access, and these collaborative conversations form the basis of the project. Stuart Keeler writes of participatory

SEA,

"in these quiet activist-engaged projects, the audience/public becomes a participant in the situation defined by the artist. The non-literal art object is manifested by the shared cohesion of artist and viewer. While art has arguably always sought to create a mediated experience, Service Media ${ }^{26}$ aims to create a moment in which the viewer can negotiate this experience, using conversation as a key factor." 27

Once the 'audience/public' becomes a participant in Papalia's project (whether it be an eyes-closed walk or our $L K I T$ tactility dialogue), they necessarily become invested in the topic at hand, and join the conversation and community of thinkers.

\section{Conversation}

One of the most critical tools of Papalia's practice is his communication with others. Working hand in hand with collaboration, conversation is the bridge that enables ideas and enthusiasm to be shared, and bonds to be formed. Helguera acknowledges that there is very little "literature studying the dynamics of conversations taking place in contemporary art." ${ }^{28}$ Research in this area is nascent, and Papalia's practice serves as an example to be studied. A critical

\footnotetext{
${ }^{26}$ Keeler's term for socially engaged art.

${ }^{27}$ Keeler, S. P., and Juliana Dreiver. Service Media: Is It "Public Art" or Is It Art in Public Space?: A Collection of Essays. Chicago: Green Lantern Press, 2013, 3.

${ }^{28}$ Helguera, Education for SEA, 40. In my own research, I have found some other examples of conversation used in contemporary art and SEA in Grant Kester's Conversation Pieces and Shannon Jackson's Social Works: Performing Art, Supporting Publics. However, Papalia's practice stands alone in its focus on accessibility activism and especially in tackling the topic of accessibility and tactility in contemporary art.
} 
breakdown of conversation as a tool is needed. "If our intention is to truly understand verbal exchange with others as a tool, we must gain a nuanced understanding of the relationship between art and speech and reflect on the way in which one affects the other." 29

A representative point for analysis is one of Papalia's earliest published efforts in SEA practice, a written conversation between the artist and Temporary Services ${ }^{30}$ as part of the Reference Points series, dating from $2013 .{ }^{31}$ This conversation serves as a predecessor to our current Let's Keep in Touch project. In his letter, he introduces himself, notes his background in literature and his visual impairment, proclaims his commitment to promoting accessibility, and expresses his interest in the work of TS. He writes, "my own personal struggle (I'm visually impaired) with regard to accessing things like print materials, public space and the institutional structure lead me to develop work that both encourages and problematizes accessibility - a practice that I have been devoted to for a year and a half now."32 He goes on to share about his work in institutional settings including a story of his experience working in a camp with

\footnotetext{
${ }^{29}$ Helguera, Education for SEA, 41.

30 Temporary Services is a collaboration between Brett Bloom and Marc Fischer, which produces everything from events to exhibitions to interventions to publicaitons. They are based in the Midwest US.

${ }^{31}$ Papalia, Carmen. Temporary Services with Carmen Papalia. Edited by Jen Delos Reyes. PSU Art and Social Practice Reference Points. Portland, OR: Publication Studio, 2013. http://a.nnotate.com/docs/2014-05-12/QUc9qIW4/RP_1_TEMP_FINAL_REV.pdf. Written while Papalia was a graduate student in Harrell Fletcher's Art and Social Practice MFA program at Portland State University, the conversation was part of the Reference Points series, coordinated by Fletcher and Jen Delos Reyes. Included in the documented dialogues is the following: a letter from Papalia to Temporary Services, a response from Temporary Services to Papalia, and then a documented interview between them. Also included is an essay by Abigail Satinsky about her path of study and work in social practice and Temporary Services, and a set of five case studies. Our focus is on Papalia's contributions, specifically his initial letter to TS. A copy of this letter is included as an addendum to the thesis.

${ }^{32}$ Papalia, Carmen. Temporary Services with Carmen Papalia, 8.
} 
youth with visual impairments, and convey how the impact of such an endeavor convinced him of the power of working at an individual level. He convincingly notes his change in approach, "the institutional approach to providing support was not as productive as a one-on-one, meaningful experience."33 Papalia then shares some examples of his early interventions such as the Long Cane. ${ }^{34} \mathrm{He}$ ends by explaining how his work aligns with that of Temporary Services in "promoting and problematizing accessibility" and closes his letter with a clear yet open invitation, "it is at this conceptual starting point that l'd like to open our conversation." 35

This letter serves as a precedent in Papalia's work, consisting of components which repeat in later projects and allowing us to break down his conversational process into structural elements. Evident in this example are these components: clear communication of ideology, personal details, storytelling, aligning of goals, and an open ask. These properties are evident in each of Papalia's projects since, and function to build community, accord, open discourse, and trust-based relationships.

In presenting his case in such a straightforward, cordial manner, he is able to share his enthusiastic interest and honest questioning of what would otherwise be quite an antagonistic topic: the socio-political critique of accessibility. Again, this characterization holds true throughout his body of work, and is especially mirrored in the current project of $L K I T$, in which he seeks to redefine museum

\footnotetext{
33 Ibid, 9.

${ }^{34}$ Papalia's Long Cane, which will be discussed further in chapter five, was an early project in which he walked the streets of Vancouver, BC, with a $14 \mathrm{ft}$. cane and videotaped people jumping out of the way.

${ }^{35}$ Papalia, Carmen. Temporary Services with Carmen Papalia, 9.
} 
engagement and accessibility policy through individual artists' permission for tactile access to their works. In $L K I T$, he uses the tool of conversation on more than one level: his dialogue with the artists, his engagement with the institutions housing the works, his collaborative conversations with the organizing curator, and his sharing of these conversations with and seeking of input from participating visitors to the exhibition (and future visitors who interact tactilely with the chosen works in other institutions). This complexity shows a development from his early work cited above, that of his letter to Temporary Services.

Conversation, no doubt, is Papalia's primary tool and plays a critical role in the negotiating of roles and strategic interventions of his work. His premises depend upon dialogue and participation in order to bring awareness to and rethinking of accessibility. The present project, Let's Keep in Touch, is deliberately named in reference to Carmen's desire to begin conversations about access which will grow through the building of relationships and continue over time.

\section{Collaboration}

"Collaborations could be expansive and risky; accessibility didn't mean leaving behind criticality; art-world infrastructures could be leveraged for resources and publicity without collapsing into cynicism." ${ }^{36}$ This pithy quote from Abigail Satinsky, who worked in her early career with Temporary Services in

\footnotetext{
${ }^{36}$ Satinsky, Abigail. "Essay." in Papalia, Carmen. Temporary Services with Carmen Papalia. Edited by Jen Delos Reyes. PSU Art and Social Practice Reference Points. Portland, OR: Publication Studio, 2013. http://a.nnotate.com/docs/2014-0512/QUc9qIW4/RP_1_TEMP_FINAL_REV.pdf.
} 
Chicago, foretells how Papalia's then future collaborative approach has come to be.

\section{Forms of collaboration}

Papalia's works are collaborative on two levels: democratic collaboration with the audience, and logistical collaboration with other art professionals.

The fact that most of Papalia's projects function by having audience participation verifies the collaborative nature with the participants. As Grant Kester writes in regard to Adrian Piper's street and public performances, "we see a shift away from the privileging of the object and toward a process of intersubjective exchange that is responsive to the specific situation of both the artist and his or her collaborators." ${ }^{37}$ This exchange is the meat of Papalia's work. The collaboration with the participants enables meaning to be made, issues to be raised, and perceptions to be challenged. This characteristic holds true especially for the eyes-closed walks and museum tour interventions.

Secondly, Papalia collaborates with other art professionals constantly whether curators ${ }^{38}$, writers, other artists, museum educators, outreach coordinators, or scholars. He is continually 'in touch' with these individuals to foster a continuing conversation transferring ideas and relating experiences with one another. Through this joint effort, relationships and foundations for future

\footnotetext{
${ }^{37}$ Kester, Grant H. Conversation Pieces: Community and Communication in Modern Art. Berkeley: University of California Press, 2004, 70-71. In thinking of Piper's Hypothesis (1968-70) street performances, I can't help but think of Papalia's Long Cane, in which he walked the streets of Vancouver with a $17 \mathrm{ft}$. mobility cane and video-taped people's reactions. The reactions of the other people were half of the work.

${ }^{38}$ In the case of our project, LKIT, Carmen is collaborating with me as a curator. Here, the questions of curator/artist artist/curator are a bit blurred. Much scholarship has been written on this topic of collaboration and roles, and may serve as future research to inform my own practice.
} 
collaborations are developed. Also, Papalia networks other individuals to each other, passing along their ideas and findings and introducing people who unknowingly share related lines of thought. These lines, via the connections formed, ultimately form bridges. In this way, Papalia creates networks and communities for transformative thought around accessibility to flourish and infiltrate institutional policy.

Both types of collaboration, whether with audience participants or with other art professionals, have a unifying thread of the sharing of ideas. In Carmen's case, these ideas are usually in regard to accessibility, and the collaborations gradually connect into a larger movement to generate paradigm shifts in thought and policy. In this way, his role is that of facilitator.

\section{Collaboration and Education}

As facilitator, Papalia is also in the role of educator in the sharing of his experiential knowledge to create situations in which participants are poised to think critically and develop insights about accessibility. Thusly, as a result of Papalia's openness to learn and share with others through collaborative dialogue, a form of education takes place. The sense given from conversations with the artist is that the collective learning and sharing process builds a network of ideas which creates a community of 'like-minded folks' ${ }^{\prime 39}$ and an atmosphere of inclusion and enthusiasm. It embodies what Helguera describes as "...an emerging form of artmaking in which art does not point at itself but instead

\footnotetext{
${ }^{39}$ A phrase Papalia has used in our conversations about building a community around the investigations of accessibility in museums.
} 
focuses on the social process of exchange. This is a powerful and positive reenvisioning of education that can only happen in art, as it depends on art's unique patterns of performativity, experience, and exploration of ambiguity." 40 The "social process of exchange" points back to Papalia's tool of conversation to create learning opportunities, and also the interactive nature of his eyes-closed walk experiments. Indeed, Papalia's format of using participatory art and conversations for stimulating critical thinking about socio-political change for accessibility is best summed up in "...the fact that knowledge of art does not end in knowing the artwork but is a tool for understanding the world. ${ }^{41}$ In Papalia's case, it is not only a tool for understanding the world, but for questioning our perceptions of it.

Theories of aesthetics to consider in application to Papalia's social practice of participatory conversations: relational, social, and dialogical aesthetics

As conversation is a major tool in Papalia's approach to socially engaged art, it is beneficial to analyze his methods through the process of critical discourse. The following theories of aesthetics lend elucidation and insights into the strategic activism at play in Papalia's use of dialogue in participatory structures.

\footnotetext{
${ }^{40}$ Helguera, Education for SEA, 81.

${ }^{41}$ Helguera, Education for SEA, 80.
} 


\section{Relational aesthetics and conversations}

It is out of relational aesthetics that the next generation of socially engaged art, social practice, has sprung. ${ }^{42}$ However, social practice "democratizes the construct [RA], making the artist into an individual whose specialty includes working with society in a professional capacity." ${ }^{\prime 3}$ Along these lines, it also distances itself from the term of aesthetics, or art, and focuses rather on the 'practice' of social engagement and activism.

Still remain some points in the discussion of relational aesthetics which are pertinent to social practice and to Papalia's work. Bourriaud, in his aesthetic paradigm dialogue, references Félix Guattari, paraphrasing, that "the aesthetic paradigm is called upon to contaminate every chord of discourse, and inoculate the venom of creative uncertainty and outrageous invention in every field of knowledge. ${ }^{44}$ This statement is in response to scientific or connoisseurship claims to certainty and irrevocability. Truly, social practice carries on these efforts, and encourages questioning and subversive, creative activism which points out the subjective nature of much that we hold certain. There are notes of this in Papalia's efforts to question which senses we employ to experience art, and in questioning institutional assumptions about the structures for experiencing art. Additionally, Bourriaud writes of "revolution through method" in that in both art and literature, "the task of each concrete performance is to evolve,

\footnotetext{
${ }^{42}$ Relational aesthetics, a reference describing a movement of socially engaged art in the 1990s, its terminology and ideology derived from the work of Nicholas Bourreard, deserves a mention and at least nominal discussion here.

${ }^{43}$ Helguera, Education for SEA, 3.

${ }^{44}$ Bourriaud, Nicolas. Relational Aesthetics. Dijon: Les Presses Du Réel, 2009, 96.
} 
innovate...without lay[ing] claim to guaranteed theoretical foundations;" ${ }^{45}$ and that "thought originates from an art, which is not synonymous with rhetoric." ${ }^{46}$ Socially engaged artists such as Carmen are still heeding this idea through their practice, in that though SEA, artists reference other disciplines to inform their work, but in the end, the aim of the work is to break new ground and form new lines of questioning.

Lastly, relational aesthetics offers us the notion that "the most pressing thing...[is] the freeing-up of inter-human communications, the dimensional emancipation of existence. ${ }^{47}$ Is this not what Papalia's interventions offer us? He addresses difficult issues in accessibility, not through angry attack, but through open, inclusive communication -- by asking questions and inviting others into shared experiences which position them to think openly, and potentially, differently. Papalia's work functions as an active invitation to think more broadly about access, and everyone who joins this discussion helps build the community of emerging thought about the subject.

Along these lines, Bourriaud notes the democratic aspect of certain works (in reference to Gonzalez-Torres and others). ${ }^{48}$ Papalia's practice operates

\footnotetext{
${ }^{45}$ Guattari, Félix, The three ecologies, Athlone Press, 2001, in Bourriaud, Nicolas, Relational Aesthetics, 96.

${ }^{46}$ Bourriaud, Nicholas, Relational Aesthetics, 96.

${ }^{47}$ Bourriaud, Nicholas, Relational Aesthetics, 60.

${ }^{48}$ In speaking of the democratic concern in certain works, Bourriaud writes, "For art does not transcend everyday preoccupations, it confronts us with reality by way of the remarkable nature of any relationship to the world, through make-believe." These works "are governed by a concern to 'give everyone their chance,' through forms which do not establish any precedence, a priori, of the producer over the beholder...but rather negotiate open relationships with it, which are not resolved beforehand. This latter thus wavers between the status of passive consumer and the status of witness, associate, customer, guest, co-producer, and protagonist. So beware: we know that attitudes become forms [compare to Joseph Beuys 'thinking is form'], and we should now realise that forms prompt models of sociability." Bourriaud, Relational Aesthetics, 57-58.
} 
under a democratic assumption as well, in that though he provides the premise and beginning structure in each of his intervention and conversation projects ${ }^{49}$ (whether an eyes-closed walk, or a documented conversation about access), the participation of the 'audience' is what makes the work. These projects of Papalia's are open dialogues, a call and response; without the participants, they could not function.

\section{Social aesthetics}

Lars Larsen clarifies the ideology of socially engaged art-making in his Social Aesthetics, in light of his involvement in the social practice movement in Copenhagen and Scandinavia at large. Two of his points in particular lend elucidation to Papalia's projects in terms of performance, democratized participation, and institutional critique.

"The distinction between art and other realms of knowledge is made operative in the osmotic exchange between different capacities to do things, which opens up the creation of new subject positions and articulations of democratic equivalence. The same thing goes for the dichotomy of institutional/ non-institutional space....art and the art institution as resource become frames for activity that is real, because social interaction and the observation of its effects are allowed without conceptual rigidity." 50

\footnotetext{
${ }^{49}$ Please see my classification schema of Papalia's projects in chapter five under his exhibition history.

${ }^{50}$ Lars Bang Larsen. "Social Aesthetics // 1999." in Bishop, Claire, ed. Participation. London: Whitechapel, 2006, 172.
} 
Again, the democratic aspect of socially engaged work is called upon, as well as its interdisciplinary potential. Both are evident in Papalia's practice in that he democratizes his processes through open dialogue and participation, and he draws upon his experiences in non-visual learning and experiencing to share with his participants. Though he critiques socio-political assumptions and barriers of accessibility, he often uses institutional art spaces to do so. These institutional spaces allow him the freedom to question and critique both socio-political and institutional issues of accessibility in a protected environment and discourse.

Larsen goes on to say, in his discussion of SEA and social aesthetics, "artistic work assumes a general focus on performance in a social perspective, either by means of its own nature as an ongoing project without closure or by the real activity it occasions." ${ }^{51}$ Both of these instances are apparent in Papalia's projects. His presentation of mobility devices, ${ }^{52}$ such as the Long Cane, the Sound Cane, and the Marching Band, are clearly performances in their very nature, as the artist performs his movement through space with the highlighted devices. His conversational works (such as that with Temporary Services and $L K I T)$ fall under the "ongoing project" categorization in that the dialogue between the artist and correspondee becomes an ongoing stage for highlighting and problematizing accessibility.

\footnotetext{
${ }^{51}$ Lars Bang Larsen. "Social Aesthetics," in Bishop, Claire, Participation, 173.

52 See chapter five, annotated exhibition history for further project descriptions.
} 


\section{Dialogical aesthetics}

Jürgen Habermas's The Theory of Communicative Action argues for "a type of social action geared to communication and understanding between individuals that can have a lasting effect on the spheres of politics and culture as a true emancipatory force." ${ }^{53}$ Papalia's practice epitomizes this action. In the LKIT project, Papalia is aiming to make lasting changes in the institutional infrastructure down to the level of catalogue files, which will change how art works are experienced in museum settings. Through talking directly with the artists themselves, he is asking for these changes to be instituted in the museum(s) in which the artists' works are housed. For these major works to be touched will require conservation efforts on the part of the museum, as well as special supervisory attention for individuals touching the works. But, in the end, these changes are a beginning step in repositioning and realigning of how art is experienced and posing questions about multisensorial engagement to society at large. Papalia also epitomizes what Helguera refers to as a "true emancipatory force" in that his work functions as "strategic infrastructural activism toward a liberatory social system that allows for wellness, agency and thriving for those who face barriers as the result of disabling social and cultural conditions. ${ }^{" 54} \mathrm{He}$ spreads this emancipation by building inclusive communities in which open dialogue, collaborative exploration, respect, and critique are encouraged.

\footnotetext{
${ }^{53}$ Helguera, Education for SEA, 7.

${ }^{54}$ Papalia, Carmen. "Re: Thesis." E-mail to Whitney Mashburn. March 31, 2016.
} 


\section{CHAPTER TWO: INSTITUTIONAL CRITIQUE}

\section{Introduction}

For the purpose of this focused investigation, it will suffice to present a brief history of institutional critique, with relevant examples highlighted in comparison to Carmen Papalia. His practice, while rooted in institutional critique, moves past the first and second waves of the movement and redirects the focus of critique onto accessibility in institutions. This critique of accessibility is what makes him stand apart.

\section{Inclusive activism for accessibility}

In 2009, Gerald Raunig and Gene Ray, in an anthology attempting to define and discuss the future of institutional critique, described what they saw as three waves of the movement. They depicted the initial round of the 1960s and '70s, led by Hans Haacke, Robert Smithson, Marcel Broodthaers, and others as "investigat[ions of] the conditions of the museum and art field, aiming to oppose, subvert or break out of rigid institutional frameworks." ${ }^{55}$ Raunig and Ray see the patterns of a second attempt of institutional critique in the late 1980s and ' 90 s, though the work of artists such as Fred Wilson and Andrea Fraser. "To the economic and political discourses of their predecessors...[they] added a growing

${ }^{55}$ Raunig, Gerald, and Gene Ray, eds. Art and Contemporary Critical Practice: Reinventing Institutional Critique. London: MayFlyBooks, 2009, xv. 
awareness of the forms of subjectivity and the modes of its formation." ${ }^{56}$ During the time of their writing (2005-09), they posited the existence of yet a third phase and its focus on activism: "this tendency towards new activist and instituent practices is one direction in which practitioners and theorists are actively attempting to renew and reinvent institutional critique under difficult contemporary conditions. ${ }^{" 57}$ Paplia's practice embodies this activism, yet refocuses it toward accessibility with a transparent, participatory structure.

Papalia's activist approach centers around access. The situations he constructs allows participants new avenues to experiencing art objects and the surrounding environment. The duality of his approach is this: (a) often playful, with jubilant enthusiasm and curiosity to explore and learn alongside the participant(s); and (b) at the same time antagonistic, subversive, and completely challenging of assumed protocols and norms. Combined, he goes about this challenging in a curious, open way in which he invites others to participate and feel at ease. It is this inclusion and enthusiasm that makes Papalia's approach so successful. Through his genuine ardor and inclusive attitude, he spreads his ideas and questions for others to ponder and to rethink assumptions, societal barriers, and institutional policies.

Critical players in institutional critique: Implications regarding Papalia's practice Hans Haacke, Fred Wilson, Mark Dion, Barbara Krueger, Jenny Holtzer, the Guerilla Girls, Adrian Piper, Andrea Fraser, and Chris Vargas all serve as

\footnotetext{
${ }^{56}$ Raunig and Ray, Reinventing Institutional Critique, xv.

${ }^{57}$ Raunig and Ray, ibid.
} 
prime examples of artists practicing and having practiced institutional critique in their work. For the sake of this concise discussion, Andrea Fraser, Adrian Piper, and Chris Vargas will be our main examples to analyze Papalia and his form of critique. Comparative discussions will follow for Vargas' MOTHA (2013-present), Piper's Hypothesis (1968-70) and My Calling (Card) \#1 (1986-90), and Fraser's from the critique of institutions to an institution of critique (2005).

\section{Conceptual collections as institutional critique: Chris Vargas' MOTHA and LKIT}

In a phone conversation regarding Let's Keep in Touch, Carmen shared a potential framing for my curatorial choices of artists: that of building a collection. As an example, he referenced a fellow contemporary artist, Chris Vargas, who has created MOTHA (Museum of Transgender Hirstory and Art) as an alternative collection to the that of the canon. Hirstory, which itself references "Herstory" from feminist history, is a virtual collection and collective which aims to represent transgender and gender non-conformed art and artists, providing widespread programming and exhibitions. ${ }^{58}$

Carmen alluded to Vargas' MOTHA as an example of creating a collection which is not in a brick-and-mortar building with the objects gathered in a single locale, but rather a virtual collecting of objects which function together as a whole, conceptually. In a similar manner, our tactilely accessible art objects will function together as a conceptual whole, as a collection, no matter the actual location / home institution of the included objects. It is with this in mind that I

\footnotetext{
${ }^{58}$ Vargas, Chris. "MOTHA: Mission Statement." Museum of Transgender Hirstory \& Art. October 2013. http://www.sfmotha.org/.
} 
began building the tactile access collection with the sculpture and textile department. As noted in the introduction, other media will follow in levels of finer gradient of tactility. The idea of alternative collections in conceptual formats is its own form of institutional critique. These collections function to challenge societal norms, assumptions, and barriers, through the critique of the manifestation of these assumed norms within institutions.

\section{Street Interventions and Correspondence: Adrian Piper and Carmen Papalia}

Papalia and Piper share three similarities to note here: that of their interactive work on the street and stimulating responses from the public, their use of conversation, and their performance of 'otherness.' Both artists utilize these frameworks and strategies in what may be considered 'institutional critique' of societal barriers and perceptions.

In Piper's Catalysis (1971), she interacted with the public (on the street, on public transportation, in a library) by demonstrating unusual actions or manners of dress, and recorded their reactions. ${ }^{59}$ Similarly, in Papalia's Long Cane (2009), he went out of the realm of socially expected behavior and walked the streets of Vancouver with a cane eight times the length of his standard issue white cane, and videotaped the reactions of people to his use of it. He writes that using the long cane "establish[ed] a buffer that would keep unwanted help at bay. Even better, I could throw a bit of the difficulty of negotiating public space as a cane

\footnotetext{
59 "Her goal was to observe the various reactions of bystanders to behaviors that violate normal categories of human social interaction and decorum." quote from Kester, Grant $\mathrm{H}$. Conversation Pieces: Community and Communication in Modern Art. Berkeley: University of California Press, 2004, 70.
} 
user back at the world by becoming an imposing moving obstacle for others. At last, I could reinforce my presence while negotiating public space on my terms." ${ }^{60}$ In an interview with Lucy Lippard, Piper notes of her public Catalysis experiments, "on the one hand, I want to register my awareness of someone else's existence, of someone approaching me and intruding into my sense of self, but I don't want to present myself artificially in any way. I want to try to incorporate them into my own consciousness." ${ }^{61}$ Is that not what Papalia has done as well? He is performing his own consciousness into the space and to the individuals surrounding him.

Piper's My Calling (Card) \#1 (1986-90) serves as a second point of comparison. Here, the artist distributed a card with a message which began, "Dear Friend, I am black. I am sure you did not realize this when you made/laughed at/agreed with that racist remark..."62 when she deemed it appropriate. Two parallels are relevant here: the dichotomy of straightforward, cordial correspondence issuing a scathing critique which cuts to the heart of inappropriate stigma and prejudiced barriers; and the performance of 'otherness.' Though Piper's correspondence is a bit more blunt than Papalia's and carries a bit more antagonistic emotion, they both are pointing to concerns of societal

\footnotetext{
${ }^{60}$ Papalia, Carmen. "You Can Do It With Your Eyes Closed." ART21 Magazine. October 07, 2014. http://blog.art21.org/2014/10/07/you-can-do-it-with-your-eyes-closed/\#.V2NmjuYrKT8. ${ }^{61}$ Lippard, Lucy, and Adrian Piper. "Catalysis: An Interview with Adrian Piper."The Drama Review: TDR 16, no. 1 (1972): 76. doi:10.2307/1144734.

62 The self-explanatory note continues, "in the past, I have attempted to alert white people to my racial identity in advance. Unfortunately, this invariably causes them to react to me as pushy, manipulative, or socially inappropriate. Therefore, my policy is to assume that white people do not make these remarks, even when they believe there are no black people present, and to distribute this card when they do. I regret any discomfort my presence is causing you, just as I am sure you regret the discomfort your racism is causing me. Sincerely yours, Adrian Margaret Smith Piper". Courtesy of the artist, in Kester, Grant H. Conversation Pieces: Community and Communication in Modern Art. Berkeley: University of California Press, 2004, 72.
} 
barriers though the format of a personal note. Also, just as Piper is creating a performance based on her experience of carrying a societally-placed label of blackness, so Papalia is creating a performance of his experience of carrying a societally-placed label of blindness. In both instances, the artists are amplifying their presence, and critiquing the socio-political marginalizing barriers in place.

Operating from within the institution: Andrea Fraser's logic and Carmen Papalia Andrea Fraser, in her Artforum essay from 2005, From the Critique of Institutions to an Institution of Critique, posits that institutional critique operates from within the institutional structure of the art world. ${ }^{63}$ Also, the institution functions as the container for such critique, and the art institution itself is made up of not just the museums and galleries and art objects, but also its people (art professionals, museum-goers, etc) and their thoughts and perceptions. It is a social being.

"It [the institution of art] is also internalized and embodied in people. It is internalized in the competencies, conceptual models, and modes of perception $^{64}$ that allow us to produce, write about, and understand art, or simply to recognize art as art, whether as artists, critics, curators, art historians, dealers, collectors, or museum visitors...these competencies and dispositions determine our own institutionalization as members of the field of art. They make up what Pierre Bordieu called habitus: the 'social made body,' the institution made mind." 65

\footnotetext{
${ }^{63}$ Fraser writes, "It could only have emerged within, and like all art, can only function within the institution of art." Fraser, Andrea. "From the Critique of Institutions to an Institution of Critique." In Institutional Critique: An Anthology of Artists' Writings, edited by Alexander Alberro and Blake Stimson. Cambridge, MA: MIT Press, 2011, 414. (originally published in Artforum 44, no.1(September 2005): 278-283, 332.)

${ }^{64}$ Emphasis mine.

${ }^{65}$ Fraser, Andrea. "From the Critique of Institutions to an Institution of Critique." In Institutional Critique: An Anthology of Artists' Writings, 413-14.
} 
Papalia challenges and critiques these very 'modes of perception' that Fraser notes. Through the conceptual rigor of his practice and the strategic structure of his interventions, he causes these living beings to rethink their modes of perceiving art (i.e. access and multi-sensorial engagement, and specifically in $L K I T$, tactile access to art within the white cube). He uses the framing of the institution to ask these questions of perception, while at the same time critiquing the perceptions within the institution.

"It is artists -- as much as museums or the market -- who, in their very efforts to escape the institution of art, have driven its expansion. With each attempt to evade the limits of institutional determination, to embrace an outside, to redefine art or reintegrate it into everyday life, to reach 'everyday people' and work in the 'real' world, we expand our frame and bring more of the world into it. But we never escape it."

Fraser speaks of the 'real world.' Does not Papalia also utilize the platform of art practice to execute social critique of access and visual/non-visual perception? Indeed, in this way, he emerges from the within to critique the 'real world' barriers to access, the socio-political stances privileging visual perception ${ }^{67}$ which permeate the minds of Fraser's 'everyday people,' and thusly further broaden the frame of not only art, but how it is experienced.

The Collective Audit of the Vancouver Art Gallery and the emancipatory stance of Gallery Gachet

\footnotetext{
${ }^{66}$ Fraser, Andrea. "From the Critique of Institutions to an Institution of Critique." In Institutional Critique: An Anthology of Artists' Writings, 414.

${ }^{67}$ Papalia reflects on his early moves into critique, "In every aspect of my life: from the way I made relationships to my experiences navigating the various cities that I lived in, I felt as if my access was compromised by the visual biases of those who had come before me." from Papalia, "For a New Accessibility," 2016, to be published as chapter in an anthology.
} 
Papalia's most pronounced example of institutional critique is the project he headed up at Gallery Gachet in his hometown of Vancouver, BC, this past December, 2015. It was through this project that a group of local artists, part of the collective at Gachet, came together to complete a critical audit of the nearby Vancouver Art Gallery, with the ensuing assessment being presented at Gallery Gachet. In the project, the group of artists, known as the New Access Consortium, upon visits to the Vancouver Arts Gallery and a three-month workshop on open access led by Papalia, took their own individual stances in critiquing the accessibility of the institution, based on their own respective area of expertise and reactions to the institution's accessibility. ${ }^{68}$ One of the critiques was a red-line edit of one of the VAG interpretive texts, rewriting marginalizing language in regard to indigenous peoples of the region, the original text authored by the Director of the VAG herself. The collective critiques "point[ed] to histories of marginalization and cultural violence, and illuminat[ed] the disabling power structures that limit one's agency and potential to thrive." ${ }^{\text {"P }}$ Papalia's leadership, in promoting accessibility, is growing and developing as part of his practice. This example shows the rich potential of what can be realized with diverse voices all pointing to gaps in accessibility and giving suggestions for change.

\footnotetext{
68 "The New Access Consortium is the collective, decentered, non institutional organizational structure initiated by artist Carmen Papalia through which a fluid cast of members are supported in assessing the conditions of access in public and institutional spaces." from "The New Access Consortium Presents: A Collective Audit of the Vancouver Art Gallery." Gallery Gachet. November 2015. http://gachet.org/exhibitions/the-new-access-consortium-presents-a-collectiveaudit-of-the-vancouver-art-gallery/.

69 "The New Access Consortium Presents: A Collective Audit of the Vancouver Art Gallery." Gallery Gachet. November 2015. http://gachet.org/exhibitions/the-new-access-consortiumpresents-a-collective-audit-of-the-vancouver-art-gallery/.
} 
Gallery Gachet's premise is important to note as well. The gallery community aims to create an environment which is empowering for all artists, with a mantra of "art is a means for survival." ${ }^{70}$ Their mission states, "through artistic means, we aim to demystify and challenge issues related to mental health and social marginalization in order to educate the public and promote social and economic justice."71 Papalia's focus on accessibility falls directly in line with that of Gachet, and it is a fitting home space for his socially-engaged critique of international proportions. Certainly, what makes Papalia's work stand alone in the realms of social practice and institutional critique is his focus on a new model of accessibility. In the next chapter, the manner in which disability studies informs this model of open access will be considered.

\footnotetext{
70 "About." Gallery Gachet. http://gachet.org/about/.

71 "About." Gallery Gachet. http://gachet.org/about/.
} 


\section{CHAPTER THREE: DISABILITY STUDIES}

\section{Introduction}

The field of disability studies has only recently begun to significantly impact contemporary art and its dialogue. Consequently, there is a paucity of research on the subject, and much of it centers around the disabled body ${ }^{72}$ and the gaze. Though the body is a critical topic for discussion, the focus in this thesis centers around the current breaking through of disability studies into curatorial practice and audience engagement at the conceptual level. Key pieces which will inform this discussion are the social model of disability, consideration of attitudes in former museum access literature, the research and activism of Amanda Cachia, the performance of disability, and most importantly - Papalia's new model for accessibility.

\section{The social model of disability}

As an entry point to the discussion, the social model of disability forms a critical foundation for further discourse around museum accessibility and Papalia's approach. The social model of disability is important to recognize here, because Papalia's practice, and my perspective and training as well, are both

\footnotetext{
72 Insightful texts tackling this topic include: Tobin Siebers' Disability Aesthetics, Ann MillettGallant's The Disabled Body in Contemporary Art, Alice Wexler's Art and Disability, and countless articles.
} 
informed by it. The initial ideology grew out of Britain in the late 1960s from a small group inspired by Marxism, the Union of Physically Impaired Against Segregation, and has evolved much since its beginnings. The main point of the social model of disability asserts that it is society which disables individuals, through "social oppression, cultural discourse, and environmental barriers." ${ }^{73}$ In this way, disability is a social construct, created by societal and environmental barriers which inhibit the agency of individuals with impairments. In sum, it is not an impairment which disables a person, but rather the barriers and constructs inherent in society. It is operating under this assumption of societal barriers that the discourse of this thesis will continue. ${ }^{74}$

Problematic attitudes and language

Most of the former literature on the topic of museum accessibility and visual impairment is laced with unintentional bias, dehumanizing stigma, and assumed barriers. Anderson and O'Sullivan note, "museums therefore must be mindful of the terms that they use and attempt to avoid the use of language which perpetuates approaches to disability which today are viewed as

\footnotetext{
${ }^{73}$ Shakespeare, Tom. "The Social Model of Disability." In The Disability Studies Reader, edited by Lennard J. Davis. New York: Routledge, 1997.

${ }^{74}$ Along the lines of institutional critique as related to the social model, Carmen writes of his experience with the Canadian National Institute for the Blind (CNIB), "The more I questioned the institution and proposed alternative support services that had the potential to work for me, the more I was convinced that it was the institution itself that was the primary disabling factor in my life." He furthermore removed the reflective red and white tape off of his standard issue cane, distancing himself from the societally-accepted institutional model.

Papalia, Carmen. "For a New Accessibility." 2016. to be published in a forthcoming anthology of disability studies.
} 
demeaning and oppressive. ${ }^{.75}$ Such literature follows the assumption that the museum is catering to individuals with limitations, and is thusly very paternalistic. ${ }^{76}$ Inherent is an institutional power structure which privileges museum leadership, an "org chart" per se, over a model for more open accessibility and the agency of the patron/visitors.

The scope of former literature about disability and museums is very limited and most always simply gives instructions on following $\mathrm{ADA}^{77}$ regulations. ${ }^{78}$ Often, when speaking to museum professionals, the written guides place museum accessibility under the umbrella of physical building accessibility or that of the education department. If the written guide is aimed to an audience of potential museum patrons, it simply notes which forms of physical access and specialized tours are available in which institutions by location listing.

Other writings on disability characterize individuals with impairments with stigmatized (often mistakenly well-meaning) stereotypes such as heroic, tragic, or inspirational. Missing is a sense of agency and authority on the part of the individuals with impairments. A recent study found these stereotypes to be

\footnotetext{
${ }^{75}$ O'Sullivan, Lisa, and Julie Anderson. "Histories of Disability and Medicine." InRe-presenting Disability: Activism and Agency in the Museum, edited by Richard Sandell, Jocelyn Dodd, and Rosemarie Garland-Thomson. London: Routledge, 2010.

${ }^{76}$ Titles include: Museums and the disabled (1979) published by the Metropolitan Museum of Art, A part of your general public is disabled: A handbook for guides in museums, zoos and historic houses (1987), What museum guides need to know: Access for blind and visually impaired visitors (1989), Art and the handicapped child (1972).

77 The Americans with Disabilities Act of 1990, which required public spaces such as museums to be made "accessible." A similar act took effect in the UK, the Disability Discrimination Act of 1995, which has now been replaced by the Equality Act of 2010. The US has not set forth an updated, more progressive bill to date.

${ }^{78}$ Titles include: Everyone's welcome: The Americans with Disabilities Act and museums (1998), New rules will require even greater access to museums (1990), Smithsonian guidelines for accessible exhibition design (1996).
} 
evident in the museum language and spaces as well. ${ }^{79}$ Now as much as ever, museum accessibility needs to focus on the autonomy and contributions of all visitor/patrons.

Only very recently, considerations of accessibility are attempting to wedge into curatorial thinking in order to be fully integrated, as is discussed later in this chapter in the work of Amanda Cachia. There is a need to adopt aspects of the social model - acknowledging socio-political (not just physical) barriers in place from society which disable an individual,$^{80}$ rather than the emphasis being placed on catering to a certain impairment. ${ }^{81}$ This need is answered by Papalia's concept of Open Access, which is outlined at the conclusion of this chapter.

\section{Performing Disability}

Many of Papalia's works function as a performance of disability. Just as was discussed in the comparison to Adrian Piper's performance of blackness (see chapter two), Papalia's actions often amplify his experience of being a nonvisual learner to a larger audience. Evidence of such can be seen in his mobility device projects: Long Cane, Marching Band, and Sound Cane. ${ }^{82}$ In these instances, Papalia is not just performing disability by amplifying his presence, he is also taking over the agency of such and redefining it in his own

\footnotetext{
${ }^{79}$ Dodd, Jocelyn, Ceri Jones, Debbie Jolly, and Richard Sandell. "Disability Reframed: Challenging Visitor Perceptions in the Museum." In Re-presenting Disability: Activism and Agency in the Museum, edited by Richard Sandell, Jocelyn Dodd, and Rosemarie Garland-Thomson. London: Routledge, 2010.

${ }^{80}$ Also see writings by local Louisville writer, Cass Irwin, in "The Disability Rag" and the work of the Center for Accessible Living (CAL), Louisville.

${ }^{81}$ Dodd, Jones, Jolly, and Sandell back up this claim in their article.

${ }^{82}$ Please see chapter 5 for annotated exhibition/project history.
} 
terms ${ }^{83} \mathrm{He}$ is replacing the institutionally structured protocol of a white cane with other, louder devices which function to critique the institutionalized notion of blindness, claim his own agency, and redefine through performance the nonvisual experience.

\section{Confluence of disability studies and curating contemporary art}

Amanda Cachia is a pioneering force in curating and writing about the nascent intersections of disability studies and contemporary art, through her activism and rigorous discourse. Her article, "Disability, Curating, and the Educational Turn: The Contemporary Condition of Access in the Museum," gives a fantastic, forward thinking discussion about the convergence of curating and museum educational programming in regard to disability. ${ }^{84}$ She writes,

"If museums foresee how curators are playing a more critical role in working with their publics, rather than with objects, and if educators, too, are always already doing this kind of work, how can curators and educators work together to create meaningful and accessible experiences about disability in museums that serve a wide range of audiences?" 85

In her investigation, she interviewed several museum professionals serving at the confluence of access, education, and curating, with the goal of determining the best location for the work of disability and access in the museum. She outlines the traditional separation of curating and education, and describes the growing "educational turn" in which curators are beginning to tackle the topic of

\footnotetext{
${ }^{83}$ I would like to do further future research on this hypothesis, and use comparisons from other marginalized discourses.

${ }^{84}$ Cachia, Amanda. "Disability, Curating, and the Educational Turn: The Contemporary Condition of Access in the Museum." OnCurating.org : After the turn: art education beyond the museum, no. 24 (December 2014): 51-66. http://www.on-curating.org/index.php/issue-24-reader/disabilitycurating-and-the-educational-turn-the-contemporary-condition-of-access-in-themuseum.html\#.V1c_PJODGkp.

${ }^{85}$ Cachia, Amanda. "Disability, Curating, and the Educational Turn," 51.
} 
pedagogical materials within their exhibitions, while still keeping a distance from the often overlooked education department. She goes on to point out that the realm of disability and access is usually handled by departments other than curatorial such as exhibition design, access, and security.

With the growing trend in curatorial practice toward the educational turn, Cachia suggests that curatorial practice may be enriched by socially engaged work dealing with disability and challenging ways of 'seeing' art, citing Papalia's Guggenheim project ${ }^{86}$ as one of her examples. She writes, "within the educational turn, disability and access might also be treated as a cognitive and intellectual issue by curators; where access might be creatively employed by artists in order to challenge our ideas of what it means to engage with a work of art in very complex multi-sensorial ways." ${ }^{87}$ Perhaps it is not a niche at all, but a future direction that all curators should at least be aware of, if not active practitioners of it.

Additionally, she writes of Carmen, "while it is not very common to find a disabled artist working within a mode of socially engaged art practice in the first instance, it would be interesting to see if artists who don't necessarily identify as disabled might utilize access more creatively and conceptually in their art practices, regardless if that practice is with objects or with people." ${ }^{88}$

\footnotetext{
${ }^{86}$ The Touchy Subject, presented at the Guggenheim in 2013. The project will be described and discussed further in Chapter 5 of this thesis.

${ }^{87}$ Cachia, Amanda. "Disability, Curating, and the Educational Turn," 54. I say, why not? This is the very niche that I have been trying to investigate for my own practice, and it is refreshing to see someone else having investigated it further.

${ }^{88}$ Cachia, Amanda. "Disability, Curating, and the Educational Turn," 58.
} 


\section{Accessibility}

Carmen Papalia is in the midst of breaking new ground in the conception of accessibility. Bolstered with group input from workshops and panel discussions he has conducted on the subject, as well as his own personal experiences, he is defining the concept of Open Access and sharing its tenets as part of his activism.

It has been a process of idea development. First, Papalia distanced himself from institutionalized regulations for the blind, then he began identifying as a nonvisual learner. Given his new framing, he sought space to establish his own manner of interaction with the world: "not a physical space where I could seek refuge from a barrage of visual information, but a politics ${ }^{89}$ that would enable me to put some distance between myself and what I felt was compromising my access." ${ }^{90}$ He decided he could "improve [his] access if [he] identified the conditions that [he] found to be the most disabling and made a

\footnotetext{
${ }^{89}$ A very relevant personal note (WM): When I entered curatorial studies after examining disability studies in a rehabilitation counseling program and working as a rehabilitation counselor, I had the aim of creating a new kind of access in museums, past the simplistic requirements of the ADA and the one-size-fits-all (and personal agency-limiting) backlogged services of government vocational rehabilitation. At the time, others asked me what this might mean, what it would embody. I did not know. I did not have a realized conception for what such a concept might look like. But I knew that it needed to happen, and that I wanted to be a part of creating it. Upon finding Carmen Papalia's work and Amanda Cachia's writing, I knew I had found "my people." Through conversations to come, and sharing of ideas and thoughts, I realized that they were constructing and bringing to realization the abstract concept I had been chasing. As Carmen has recently written, this radical accessibility and open access is a "conceptual space," a personal "politics" supported by a community. It is not simply, as I have been asked by others, hanging paintings at a different height. It is rather an attitude to be adopted by museum leadership, to gather input from individuals who have been marginalized, and to transfer privilege for the enabling of empowered agency.

${ }^{90}$ Papalia clarifies, "It became clear that to thrive as a nonvisual learner I would first have to establish a space for myself within which I could find comfort; a space within which I did not feel marginalized by the conditions of visual primacy. Not a physical space where I could seek refuge from a barrage of visual information, but a politics that would enable me to put some distance between myself and what I felt was compromising my access as a nonvisual learner." Papalia, "For a New Accessibility," 2016, to be published as chapter in an anthology.
} 
dedicated effort to interrupt those conditions." ${ }^{91}$ Papalia was exposed to the term, "radical access,"92 and adopted it with his own working definition as "an approach to facilitating access that grows from the roots of a community and which is radically different than a static policy-based approach." ${ }^{93}$ In this way, he "wanted the freedom to set [his] own terms around [his] access and support."94

Papalia decided that "the museum, a platform in which only a select few have the privilege of access and mobility, ${ }^{95}$ offered the perfect context for which to conceptualize the conditions of radically accessible space. ${ }^{.96}$ Coming from a focus on creating a space of trust between museum and learner, he established a set of defining characteristics of Open Access. It is pertinent to include these tenets here, as they form the basis for Papalia's current practice and activism. The tenets are as follows:

"Open Access relies on who is present, what their needs are and how they can find support with each other and in their communities. It is a perpetual negotiation of trust between those who elect to be in support of one another in a mutual exchange.

Open Access is radically different than a model in which a set of policies is employed in order to facilitate a common experience for a group with definitive needs. It acknowledges that each participant carries a body of local knowledge and is an expert in their own right.

\footnotetext{
91 Papalia, "For a New Accessibility."

92 Papalia attributes this term to the Social Spaces Summit in Vancouver in 2013 and also to Romham Pádraig Gallacher's Radical Access Mapping Project.

93 Papalia, "For a New Accessibility."

94 Papalia, ibid.

95 The following quote is from Papalia's early conversation with Temporary Services. It shows the continuity of his thinking throughout the course of his practice. "The [art] institution has designed a visitor experience around what one can gather through their visual sense. Audible and various 'accessible' tours (which are often just offered once every week or two) are helpful, but still exist as a less-than-equal substitute for the privileged, visual experience. This limited access to cultural learning....points to a deep-rooted problem in how the institutional model is limited in serving diverse communities." Papalia, Carmen. Temporary Services with Carmen Papalia. Edited by Jen Delos Reyes. PSU Art and Social Practice Reference Points. Portland, OR:

Publication Studio, 2013. http://a.nnotate.com/docs/2014-0512/QUc9qIW4/RP_1_TEMP_FINAL_REV.pdf.

${ }^{96}$ Papalia, ibid.
} 
Open access is the root system of embodied learning. It cultivates trust among those involved and enables each member to self-identify and occupy a point of orientation that is based in complex embodiment.

Open Access interrupts the disabling power structures that limit ones agency and potential to thrive. It reimagines normalcy as a continuum of embodiments, identities, realities and learning styles, and operates under the tenet that care and a shared accountability among participants are core components of liberated space.

Open Access is emergent, collectively-held space in which members can find comfort in disclosing their needs and preferences with one another. It is a responsive support network that adapts as needs and available resources change." ${ }^{97}$

The most brilliant aspects of Open Access are that it calls upon the knowledge of individuals, and yet at the same time, it functions as these same individuals are bolstered by a community of support and advocacy. Prior attempts at accessibility have offered a limited 'catering' to groups with certain 'needs,' but have not privileged the voices of the individuals and their body of knowledge and experience. We are all unique, it only makes sense for distinct voices of clarity to be heard and recognized.

Open Access takes the social model further in that it not only acknowledges cultural and social barriers as the disabling threats to individual agency, but it also seeks and activates strategic infrastructural interruptions to these barriers. Papalia's argument for a new accessibility is breaking new ground, not only as an improved social model, but also in its application to museum engagement and functioning. The further delving into tactility as a tool of radical accessibility asserts his dedication to putting his ideology into practice.

\footnotetext{
${ }^{97}$ Papalia, "For a New Accessibility."
} 


\section{CHAPTER FOUR: TACTILITY}

\section{Introduction}

"Touch is the unsung sense-the one that we depend on most and talk about least...we are so used to living within our skins that we allow them to introduce themselves as neutral envelopes, capable of excitation at the extremities (and at extreme moments), rather than as busy, body-sensing organs. We see our skins as hides hung around our inner life, when, in so many ways, they are the inner life, pushed outside."

The sense of touch is all-encompassing, yet it is often goes unnoticed.

Touch is most often thought of as a secondary sense to visual and even auditory perception. As we will see in this chapter, touch functions well as an integrated, complementary sense which furthers our understanding of art objects and our surrounding environment. A nascent field, tactility is yet to be fully investigated in current research, and yet has much potential for knowledge-gathering and experience enrichment. The following chapter presents past examples of tactile engagement, discusses the concept of tactile aesthetics, and most importantly, proposes a methodology for tactile analysis. Additionally, scientific perspectives are cited, the history of tactile access in museums is considered, and a few thoughts on museum engagement are shared.

\footnotetext{
${ }^{98}$ Gopnik, Adam. "Feel Me." The New Yorker, May 09, 2016. http://www.newyorker.com/magazine/2016/05/16/what-the-science-of-touch-says-about-us.
} 


\section{Tactile Engagement: past examples}

Important examples of tactile engagement to note include the Tactile Dome at the Exploratorium in San Francisco, the Elizabeth Morse Touch Gallery at the Art Institute of Chicago, and the Please Touch Museum in Philadelphia which influenced the City Museum in St. Louis.

The Tactile Dome at the Exploratorium has come up as a reference in conversation with Carmen, and he was quite enthusiastic to speak of it. This institution prides itself in presenting material of art, science, and human perception; the materials spur visitors to question, interact, and learn. The Tactile Dome, founded in 1971 by August Coppola, is a domed space of total darkness in which visitors explore the exhibits within with their non-visual senses, mainly touch and smell, while actively moving through the space. ${ }^{99}$ Carmen has said that this multisensorial approach to engagement has influenced and encouraged his ideas about tactile access.

In Chicago, the Art Institute's Elizabeth Morse Touch Gallery provides a very focused experience. Here, four portrait busts are on display, from four selected periods. ${ }^{100}$ To the credit of the Art Institute, each of these works are originals, not replicas. They have been coated with wax to protect against skin oils and other conservation threats. Though initially designed for individuals with visual impairments, the gallery is open to all visitors to touch the sculptures.

\footnotetext{
99 "Visit the Tactile Dome | Exploratorium." Exploratorium Blog. August 01, 2014. http://www.exploratorium.edu/visit/west-gallery/tactile-dome.

100 "The Elizabeth Morse Touch Gallery." The Art Institute of Chicago. http://www.artic.edu/exhibition/elizabeth-morse-touch-gallery.
} 
Perhaps we can learn from this example -- bridging the gap between tactile access to originals and conservation concerns, the use of wax allows respect for both.

Two other examples yield insights. The Please Touch Museum in Philadelphia, established in 1976, is dedicated to children and "purposeful play." ${ }^{101}$ Established in the Montessori tradition, it provides countless haptic learning interfaces, and has examples adults may learn from as well. The subsequent City Museum in St. Louis, created under the direction of sculptor Bob Cassilly, takes adult and child experiencing of exhibits even further with intensely interactive play. ${ }^{102}$ Museums such as these two fall at one end of the spectrum of audience participation, and the Art Institute's Morse Gallery falls around the middle, with traditional museum guidelines falling at the other end. So where does this leave Papalia's aims of Let's Keep in Touch? Somewhere in the middle with the Morse Gallery, yet with quietly subversive policy changes in the mix.

\section{Tactile Aesthetics}

When Carmen first talked to me about the idea of "tactile aesthetics," he noted that he had learned the term through conversations with Australian artist, Fayen d'Evie, in discussing a one-day tactile public exhibition put together by d'Evie and Georgina Kleege, an English literature professor at UC Berkley. ${ }^{103}$

\footnotetext{
101 "About PTM - Please Touch Museum." Please Touch Museum. http://www.pleasetouchmuseum.org/about/about-ptm/.

102 "About - City Museum." City Museum. http://www.citymuseum.org/visit/about/.

${ }^{103}$ More information about this exhibition will be shared later in the paper.
} 
Since then, I have run across the term in an essay by Yi-Fu Tuan, in an anthology published in 2005. ${ }^{104}$ Still others, such as Gallace and Spence, have discussed the neural correlates for tactile aesthetics in a scientific context. ${ }^{105}$ Needless to say, it appears to be a relatively new term, which I will proceed to define and expound upon through examples and my own understanding. For the purposes of choosing artists in the curatorial layer of this project, I took tactile aesthetics to mean that an art object possessed qualities of tactile contrast and variety in form and texture, without overwhelming the sense. My hope is that eventual visitors might be able to explore these objects through their skin and respond to the haptic experience, offering feedback to enrich the understanding of the object.

Yi-Fu Tuan describes the concept of tactile aesthetics as a pleasing sensation felt through the skin, ${ }^{106}$ often in response to nature, and often discounted by modern society. He writes, "the pleasures of being alive and our deepest sense of wellbeing depend on cutaneous rewards that may come anytime, anywhere" and how "touch is exploratory and hence can open up a world" ${ }^{107}$ He goes on to give multiple scenarios to highlight his understanding of tactile aesthetics, including the "roughness of a cobbled walk," the "pressure of a

\footnotetext{
104 Tuan, Yi-Fu. "The Pleasures of Touch." In The Book of Touch, edited by Constance Classen. Oxford: Berg, 2005.

105 Gallace, Alberto, and Charles Spence. "Tactile Aesthetics: Towards a Definition of Its Characteristics and Neural Correlates." Social Semiotics 21, no. 4 (2011): 569-89. doi:10.1080/10350330.2011.591998.

${ }^{106}$ An interesting scientific finding in regard to touch and pleasure: "Neuroscience research also shows that certain tactile stimuli are effective in modulating the activation of certain areas of the brain involved in the perception of pleasure." Gallace, Alberto, and Charles Spence. "The Neglected Power of Touch: What the Cognitive Neurosciences Can Tell Us about the Importance of Touch in Artistic Communication." In Sculpture and Touch, by Peter Dent, 107-24. Farnham: Ashgate Publishing Limited, 2014.

107 Tuan, Yi-Fu. "The Pleasures of Touch" in Classen, The Book of Touch, 74-75.
} 
heavy sweater," and the "warmth of a coffee cup." ${ }^{108}$ He explains that landscapes in nature have a "strong appeal" because of their "range and complexity of..tactile impress" and that "the tactile sense is activated by contrast," aspects which are imitated and repeated by landscape architects aiming for a sense of beauty. ${ }^{109}$ In the end, Tuan notes that touch is the "sense least susceptible to deception;" "the tactile sense comes up against an object, and that direct contact, felt sometimes as harsh impingement, is our final guarantee of the real." ${ }^{\prime 10}$ Could it be, then, that experiencing an object by touch is a more connected understanding of the real than passive visual observation? In this way, does this not speak volumes for Papalia's activism to include tactile access into the active vocabulary in the white cube setting? Tuan's closing point ties directly into reflections made by Georgina Kleege upon her tactile access to maquettes by Matisse housed at MoMA.

"But we not only are impinged upon by external reality; we also impinge -that is, exert force -- on it. Touch, unlike the other senses, modifies its object. It reminds us that we are not only observers of the world but actors in it. With this awareness comes pride in our ability to do and make, but a pride that is shadowed by guilt, for unmaking precedes making: we are both destroyers and creators."111

After exploring the Matisse maquettes through touch, Kleege commented on her experience as having felt in the same position of the artist, that of placing her hands where those of the artist had been in the process of creating and modifying the object. As she puts it, "here, I had the analogous pleasure of feeling a distant relative of the artist's haptic sensation as he molded the

\footnotetext{
108 Tuan, "Pleasures of Touch," in Classen, The Book of Touch, 74.

${ }^{109}$ Tuan, "Pleasures of Touch," in Classen, The Book of Touch, 77.

110 Tuan, "Pleasures of Touch," in Classen, The Book of Touch, 78.

111 Tuan, "Pleasures of Touch," in Classen, The Book of Touch, 78-79.
} 
forms." ${ }^{112}$ Might we say that her contact with the art work was more active in its incarnation than a visual observer? Did she step into the moment in which Matisse was (as Tuan would say) unmaking the object in the process of making? (These maquettes were meant as a working stage for the artist to test out ideas of transferring three dimensions into two.)

Also, along another line of interpretation of Tuan's statement, is it the "unmaking" that is exerted through the touch of visitors on art objects that museums fear in the lens of conservation efforts? It is indeed a double-sided issue, that of touch. At the same time that it provides the 'viewer' a more active understanding through experience of the object, the work also can come away somewhat modified from this activity. The object is often affected by the viewer's physical touching as well as the viewer gains haptic knowledge from the encounter with the object. In some cases, it can be argued that the gains of understanding outweigh the conservation concerns, but that this evaluation would need to be on a case by case basis, and in the case of contemporary art, that the opinion of the artist be the ultimate deciding factor.

A methodology for tactile aesthetics: examination techniques, properties, and descriptive vocabulary

In order to build structure for tactile analyses and formal criticism, one must first establish component parts for such a discourse. Such a methodology has yet to be built, therefore, a structure is proposed of the following three critical

\footnotetext{
112 Kleege, Georgina. "Some Touching Thoughts and Wishful Thinking."DSQ Disability Studies Quarterly 33, no. 3 (2013). doi:10.18061/dsq.v33i3.3741.
} 
components: a standard set of methods and techniques utilized for observation, a set of values or characteristics to evaluate in tactile analysis, and a descriptive vocabulary.

\section{Techniques of touching}

Georgina Kleege, in her collaboration with Fayen d'Evie, in The Levity, the Gravity, ${ }^{113}$ investigated objects haptically from the Kadist Art Foundation. As a result of this experience, she classified her methods into four main types of manual tactile exploration techniques. She describes these techniques as follows: manipulation, grasping, tracing with fingertips, and full body kinesthetic movement. ${ }^{114}$ Manipulation is often the technique for observing and analyzing objects which may be held in one's hand(s). ${ }^{115}$ Information may be garnered by picking up the object and manipulating it to feel different parts of it. Grasping is another method. Kleege describes this tactic in reference to exploring a piece by Adrian Wong, in which the work consists of several layered metal bars in the form of grates, mounted on the wall. ${ }^{116}$ She found that the easiest manner to determine this work's properties was by grasping the bars in different sections. Tracing the form with fingertips is yet another method for tactile examination.

\footnotetext{
${ }^{113}$ This project will be discussed further in chapter five. Further information may be found here: https://fayendevie.net/the-levity-the-gravity/

${ }^{114}$ Kleege, Georgina. "Whitney Mashburn Conversation with Georgina Kleege." Telephone interview by author. June 4, 2016. For online video footage of Kleege interacting with the Kadist objects using these techniques, see: https://vimeo.com/154934219.

115 "Cognitive neuroscience has shown that our judgments of importance, weight, attractiveness and so on can all be affected by the object that we happen to be holding in our hands." Gallace, Alberto, and Charles Spence. "The Neglected Power of Touch: What the Cognitive Neurosciences Can Tell Us about the Importance of Touch in Artistic Communication." In Sculpture and Touch, by Peter Dent, 107-24. Farnham: Ashgate Publishing Limited, 2014. ${ }^{116}$ Kadist Art Foundation. "Touch Tour by Georgina Kleege with Work by Adrian Wong." January 2016. https://vimeo.com/154934219.
} 
Whereas grasping involves the entire hand and motion of the wrist, tracing uses only the fingertips, one of the more sensitive parts of the hand, to gather more subtle details. As a fourth technique, Kleege explained that moving through a work of art with the entire body as a kind of kinesthetic exploration can also yield new information. ${ }^{117}$ This last method is especially interesting in thinking of the work of Serge Alain Nitegeka, an artist chosen for Papalia to contact in this project. These four methods should serve as the beginning of our structure for tactile analysis and critical dialogue surrounding an art object.

Scientific research supports using these multiple haptic techniques. David Linden, neuroscientist at Johns Hopkins University, noted that there are 'labelled lines' that transfer the information gathered through touch to our brains. Individual 'lines' function in combination with one another to convey different sensations. ${ }^{118}$ Therefore, the system of touch is very specialized through the use of these 'lines' and the types of touching which stimulate different combinations of feedback. Scientists have even isolated the 'line' for the sensation of itching. ${ }^{119}$ It is no wonder, then, that we have the capability to structure our

\footnotetext{
117 "The important link between touch and active movement, something that contributes to making the relationship between a person and a piece of art more intimate has been highlighted in a number of studies." Gallace, Alberto, and Charles Spence. "The Neglected Power of Touch" In Sculpture and Touch, by Peter Dent, 107-24. Farnham: Ashgate Publishing Limited, 2014, 119. Also, artist Rosalyn Driscoll writes, "knowing through touch imbues sculpture with motion and transformation that become integral to the experience, the object, and to one's self." Driscoll, Rosalyn. "Pictorial essay B: Playing with fire" in Dent, Peter, ed. Sculpture and Touch. Farnham: Ashgate Publishing Limited, 2014.

${ }^{118}$ Gopnik, Adam. "Feel Me." The New Yorker, May 09, 2016. http://www.newyorker.com/magazine/2016/05/16/what-the-science-of-touch-says-about-us. Further explanation from Linden, "These systems aren't usefully understood just as different cognitive responses to the same stimuli-they're completely different integrated systems. There are separate labelled lines for so many seemingly intermingled systems."

119 This is the research of David Ginty, of Harvard Medical School, as reported in Gopnik, Adam. "Feel Me." The New Yorker, May 09, 2016. http://www.newyorker.com/magazine/2016/05/16/what-the-science-of-touch-says-about-us.
} 
methods and techniques for tactile exploration. The potential in this area is wide open, which verifies our need to create an architecture for different modes of touching.

\section{Properties to evaluate in tactile analysis}

How then should these methods be employed? What characteristic properties may be better understood through the techniques of haptic exploration? It is necessary to begin a list of properties for tactile analysis and criticism. Just as visual analysis examines such aspects as composition, color, style, brushstroke, glaze, iconography, size, and form, there is need for a basis for tactile analysis as well. Classen, in her Book of Touch, quotes Robert Hooke, seventeenth century empirical philosopher, giving the properties he deemed relevant to examine in an object. These included: "Sonorousness or Dulness...Gravity, or Levity. Coarseness, or Fineness. Fastness, or Looseness. Stiffness, or Pliableness. Roughness, or Brittleness. Claminess, or Slipperiness." ${ }^{120}$ Upon my speaking with Kleege, she also noted characteristics such as temperature, porousness, malleability, and weight. ${ }^{121}$ These properties listed by Kleege are interesting to consider, because other than by physical touch, it would be quite difficult, if not impossible, to gather this information by sight alone. Therein lies a value in examining an object haptically, in that

\footnotetext{
${ }^{120}$ Hooke, Robert. In Arnold, K. (2003), "Skulls, Mummies and Unicorns' Horns: Medicinal Chemistry in Early English Museums," in R.G.W. Anderson, M.L. Caygill, A.G. MacGegor and L. Syson (eds) Enlightening the British: Knowledge, Discovery and the Museum in the Eighteenth Century, London: The British Museum Press. In Classen, Constance, "Touch in the Museum" In The Book of Touch, edited by Constance Classen. Oxford: Berg, 2005.

${ }^{121}$ Kleege, Georgina. "Whitney Mashburn Conversation with Georgina Kleege." Telephone interview by author. June 4, 2016.
} 
descriptive information may be garnered which is not available through visual analysis and examination. ${ }^{122}$ Spence and Gallace, in their literature review of scientific studies of touch, note that "while vision provides more accurate (or reliable) information about certain object properties, touch/haptics has been shown to provide more accurate information about others." ${ }^{123}$ There is value in adding touch to our repertoire of experiencing art.

\section{Developing a vocabulary for haptic description}

Just as the process of tactile analysis and haptic criticism is still burgeoning, tactile descriptive vocabulary is still nascent, and needs further development. When one goes to describe a particular haptic sensation or tactile quality, a paucity of vocabulary exists, especially in comparison to the other senses. A multitude of adjectives exist in the realm of taste, smell, and sound. Vision holds the most terms to describe its perceptions and observations. But yet touch has quite few, and often borrows from other senses. As Carmen and I were discussing how we might collect responses from visitors who touched Christina's piece in our exhibition or the pieces in other institutions by one of the sixteen selected artists, he noted how very few words are available for tactile description. As mentioned earlier, we would like to add tactile descriptions to museum object files, which are traditionally primarily visual in their data fields.

\footnotetext{
${ }^{122}$ Classen notes, in the context of early museums valuing touch, "using multiple senses to investigate museum objects enhanced the impression of having comprehended their nature. In general, the sense of touch was believed to have access to interior truths of which sight was unaware...touch functioned to correct the misconceptions of sight." Classen, "Touch in the Museum," in The Book of Touch, 277.

${ }^{123}$ Spence, Charles, and Alberto Gallace. "Making Sense of Touch." In Touch in Museums: Policy and Practice in Object Handling, by Helen Chatterjee, Sally MacDonald, David Prytherch, and Guy Noble, 21-40. Oxford: Berg, 2008, 27.
} 
Fayen d'Evie and Georgina Kleege, in the description of their project, The Levity, The Gravity, which will be discussed further in chapter five, also note the lack of tactile descriptive vocabulary as a result of touch becoming taboo in museum spaces after the mid-1800s: "the repercussions include tactile amnesia within art historical accounts, and a loss of language to discuss tactile aesthetics." ${ }^{124}$ Additionally, even in scientific research concerning touch, this scarcity is stressed, "the paucity of terms that we currently have...to describe the nuances of our tactile experiences with objects is brought into sharp relief by contrasting them with the widely accepted lexicon...for describing visual and auditory stimuli such as colour and pitch." 125 This deficiency of terminology makes the collection of responses and tactile descriptions in our project all the more pertinent, timely, and progressive. There is clearly a need to be met, a gap to be filled. The language of tactile aesthetics needs to grow and develop, with the gentle push of projects such as ours. Tactile aesthetics necessitates critical dialogue of its own and the vocabulary to support such analyses.

\section{From a scientific perspective}

With the exception of the Touch Lab at MIT, most of the scientific research investigating tactility in regard to museum access is taking place in the UK. Thus, this discussion will rely on the multiple literature reviews of Spence and Gallace. These two researchers have tackled the topic of tactile engagement in museums from a scientific perspective, sharing recent findings from studies on

${ }^{124}$ D'Evie, Fayen, and Georgina Kleege. "Hand(s) On: The Levity, The Gravity." FAYEN KEXIAO DEVIE. January 02, 2016. https://fayendevie.net/the-levity-the-gravity/.

${ }^{125}$ Spence, Charles, and Alberto Gallace. "Making Sense of Touch." In Touch in Museums, 30. 
touch from via several literature reviews. They point out the "limited scope of much of the psychological and neuroscientific research [on touch] published to date" and that little of the research that has been done is relevant to museum engagement. ${ }^{126}$ Many of the studies have analyzed individuals' ability to distinguish between textures. While useful in technical abilities for textile production and quality control, these studies do not contribute much to museum engagement. Still other studies offer a therapeutic perspective, citing the ways in which touch can impact the psychological well being. ${ }^{127}$ Other studies cited by Spence and Gallace in their literature review solidified the claim that our brains weight the sensorial information from our most reliable source most heavily, i.e. "sensory dominance." ${ }^{128}$ Attention and concentration can impact this factor as well. Finally, it is proposed that those who work with their hands, such as sculptors, "show enhanced visual cortical activation when haptically interacting with the kinds of objects/stimuli on which their expertise is based." 129

One key point, however, certainly speaks to the value of touch for strengthening memory of an object or experience. "Information that is gathered through multisensory stimulation (stimulation that includes the sense of touch)

\footnotetext{
${ }^{126}$ Spence, Charles, and Alberto Gallace. "Making Sense of Touch." In Touch in Museums, 22.

127 See further chapters in Touch in Museums: Noble and Chatterjee, "Enrichment Programmes in Hospitals;" O'Sullivan, "See, Touch, and Enjoy;" Rowlands, "Aesthetics of Touch among the Elderly." One of the most striking examples in the Touch in Museums text was the collaboration between The British Museum and Pentonville Prison, in which art works were brought into the prison. The works were touchable, and were used to promote discussion and stimulate creativity and conversation in accompanying workshops. The topics covered included gun control with "Throne of Weapons" and drug use through "Cradle to Grave." The exhibitions, haptic access to the objects, and workshops had the effect of breaking down barriers and creating at least temporary unity and thoughtful conversations among the prisoners. Samuels, Jane. "The British Museum in Pentonville Prison." In Touch in Museums, 253-60. Oxford: Berg, 2008.

${ }^{128}$ Spence, Charles, and Alberto Gallace. "Making Sense of Touch." In Touch in Museums, 27.

${ }^{129}$ Spence, Charles, and Alberto Gallace. "Making Sense of Touch." In Touch in Museums, 28.
} 
may provide stronger and longer-lasting memories for that information than for information acquired solely by visual or auditory stimulation." ${ }^{130}$ In other words, if one touches an object rather than just looking at it, the information about that object and the experience surrounding it are bolstered. Touch improves memory and understanding of an experience.

It stands to reason then, that multisensorial clues converge together in the brain. "Visual, olfactory, and...auditory cues are all combined by our brains in order to give rise to our multisensory perception of the texture or 'feel' of a given surface."131 This fact should be considered alongside another finding from Lore Thaler, a research professor at the UK's Durham University. She has conducted extensive cognitive neuroscientific research on the brain activity of individuals who are blind and those who are sighted, examining the receptors triggered when the individual is exposed to different stimuli. She found that individuals who are blind and use echolocation techniques (i.e. clicking with their mouth to echo sounds off of nearby objects and determine their location and properties) have the ability to form spatial images similar to sighted individuals' peripheral vision images. ${ }^{132}$ Considering the findings referenced by Spence and Gallace

${ }^{130}$ Gallace, Alberto, and Charles Spence. "A Memory for Touch: The Cognitive Psychology of Tactile Memory." In Touch in Museums, 253-60. Oxford: Berg, 2008, 179. Here, Gallace and Spence cite: Dinh et al. 1999, Farkas 2003, Hoffman et al 1998, and Murray, Foxe and Wylie 2005.

131 Spence, Charles, and Alberto Gallace. "Making Sense of Touch." The studies that Spence and Gallace are referencing here are as follows: Guest, S., Catmur, C., Lloyd, D. and Spence, C. (2002), 'Audiotactile interactions in roughness perception', Experimental Brain Research 146:16171. And Spence, C. and Zampini, M. (2006), 'Auditory contributions to multisensory product perception', Acta Acustica united with Acustica 92: 1009-25. This finding is interesting to remember in light of multisensorial exhibitions such as one to be discussed in chapter five, Amanda Cachia's Sweet Gongs Vibrating, 2016.

132 Thaler, Lore, Wilson, Rosanna C. \& Gee, Bethany K. (2014). Correlation between Vividness of Visual Imagery and Echolocation Ability in Sighted, Echo-Naive People. Experimental Brain Research 232(6): 1915-1925. 
and those of Thaler, we can realize that multisensorial cues influence our perception of tactile properties, and that auditory cues can be used by our brains to form spatial images. All of this to say, the complex connections and potentials of how our tactile sense functions are only beginning to be explored and understood.

When it comes to museum uses for touch, much of Spence and Gallace's focus is on better understanding tactility for creating replicas for visitors to touch rather than the actual art object or artifact. The Touch Lab at MIT is investigating using technology to replicate touching and feeling an object via digital simulations. ${ }^{133}$ The discussion of replica/simulation versus original is one that has been raised often in recent years, especially with the advent and popularization of 3-D printers. It certainly is a step in the direction of conservation efforts to protect the objects. In conversations with Papalia, his view on the matter is very clear. It is critical to his premise to touch the actual art object and not a replica. As he told me, the replicas, however well-constructed, a) may not include all of the tactile details of the original, and b) are secondary items to the original, i.e. the observer is being relegated to a second-class experience. These thoughts are important to keep in mind through the next section as we address museum engagement.

\section{A few thoughts on museum engagement}

\footnotetext{
${ }^{133}$ Zimmer, Robert, Janis Jeffries, and Mandayam Srinivasam. "Touch Technologies and Museum Access" in Touch in Museums: Policy and Practice in Object Handling. Edited by Helen Chatterjee. Oxford: Berg, 2008. 150-59.
} 
The concept of museum engagement is indeed morphing, and deserves at least a brief discussion here in light of our efforts to push for tactility to be integrated into museum engagement.

History of tactile engagement in museums and the value of touch

The conditioned response not to touch anything in a museum or gallery setting is relatively new since the nineteenth century. Constance Classen dedicates an entire chapter in her anthology, The Book of Touch, to describing early museum engagement, citing the Ashmolean Museum and the British Museum as her prime examples. There is much to be gleaned from Classen's history lesson, mainly the valued benefits associated with touching objects from an era in which the act was free from its current taboo.

In early museums of the eighteenth and nineteenth centuries, touching of art and artifacts was expected. Most often, the objects were observed via private tours hosted by the collection owner or the keeper of the museum. The offering of objects for touch was associated with notions of hospitality, and it was considered rude not to touch and not to offer/allow objects to be touched. Practical concerns were a contributing factor as well. As glass cases were a rarity, often objects were kept on the walls (where they were easily accessible to touch), or in drawers (where the act of taking them out for examination necessitated interaction with the object). ${ }^{134}$ Touching was not reserved only for three-dimensional objects, but paintings received haptic attention as well.

${ }^{134}$ Classen, "Touch in the Museum," in Classen, The Book of Touch, 275-76. 
Religious icons and secular portraiture were known to be even kissed, and landscapes were touched for texture of paint. ${ }^{135}$

Much can be learned from this era in which touching was encouraged and considered a complementary action to gazing with the eyes; together the two functioned together as 'looking' to enhance one's understanding of the object. Among the many benefits early museum-goers understood tactile access to provide were: insight, intimacy, bridging time and space, and a more authentic experience. Insight was garnered through tactile access in that "the sense of touch was believed to have access to interior truths of which sight was unaware."136 A clear example of this might be an object having a different physical weight than might appear to the eye. Secondly, touching objects gave a sense of intimacy. As Classen notes, "touch...annihilates distance and physically unites the toucher and the touched;" also "in the case of human-made artefacts, it also provided the thrill of coming into vicarious contact with their original creators and users." ${ }^{137}$ Thirdly, handling objects from a different time or place gave the handlers the sense of connection to that time or place of the object's origin. ${ }^{138}$ Lastly, especially in the experiencing of sculpture, touch was considered necessary. German philosopher Johann Herder "held that sculpture

\footnotetext{
${ }^{135}$ Later, Bernard Berenson noted the conceptually tactile aspects of two-dimensional works in that "a painting must possess more than just visual excellence; it must have 'tactile values' that reach out and touch, even embrace, the viewer." quoted from Berenson, Florentine Painters of the Renaissance, 1906, in Yi Fu Tuan, "The Pleasures of Touch" in Classen, The Book of Touch, 77.

${ }^{136}$ Classen, "Touch in the Museum," in Classen, The Book of Touch, 277.

${ }^{137}$ Classen, ibid. Also, this recalls the sense that Kleege had in handling the Matisse maquettes at MoMA, as discussed earlier in this chapter.

${ }^{138}$ This aspect points to a discussion of culture, and of fetishizing the other. There is much potential in this dialogue, but for need of concision, I am not able to pursue it here. I hope to do so in further discourse and research.
} 
was the highest form of art because it was perceptible to the sense of touch, for 'everything that relates to the beauty of form and of the body is the domain of touch, not of sight, a superficial sense which can only render surfaces and colors of objects."”139

We, in our current conversation about museum engagement in our tactility access project with Papalia, can take some of these values of touch from the era when touch was much less constrained. Perhaps these insights may enlighten our own perceptions of touch and counter the more recently developed notions of severe restraint and the taboo of touch. Perhaps we should look to find a balance between the hands-off approach and the unbridled, conservator's nightmare of the early museums.

How did expectations change? Classen posits a confluence of contributing reasons that attitudes toward touch in museums changed over the course of the early modern era. Some of these are: the shift in museums from private to public and associated stigmas attached to lower classes (i.e. the "uncultured touch of the masses"), the resulting social discipline enacted, the "increased reverence for museum pieces in the nineteenth century" which led to increased conservation efforts, the heightened visualism of museums paralleling a new focus on city window displays and improved lighting, and increased privileging of the visual sense via human and social evolution scholarship (i.e.

\footnotetext{
${ }^{139}$ Classen, "Touch in the Museum," in Classen, The Book of Touch, 279, citing Norton, R.E., Herder's Aesthetics and the European Enlightenment, Ithaca, NY: Cornell University Press, 1990.
} 
Darwin, Nordau, Freud). ${ }^{140}$ Of course, these changes did not happen suddenly, it was a gradual shift as each of these contributing factors came into play.

\section{Touch and control}

"In order for the taboo on touch in the museum to be effective and accepted, visitors had to internalize a number of notions. First of all, that they were less important than the exhibits on display and thus must behave deferentially, towards them. Secondly, that to touch museum pieces was disrespectful, dirty, and damaging. Thirdly, that touch had no cognitive or aesthetic uses and thus was of no value in the museum, where only cognitive and aesthetic benefits were to be sought." ${ }^{.141}$

The discussion of museum accessibility brings to mind the issue of control. The power structure of the institution, no matter how open to visitors, still by its very functioning, determines the rules and regulations by which to modify one's behavior while experiencing the art offerings. In most modern museums and still today, visitors "must learn to keep their voices low, their pace measured, and their touch restrained." ${ }^{142}$ These guidelines function to help other museum visitors be able to focus on the art that they are viewing, and for uninterrupted thinking about such works. The regulations also protect the art.

Touch came to be associated with contamination in the Victorian era as museums became public and were no longer open to only a privileged few. The image of the lower classes was associated with filth, and campaigns of sanitation and control emerged. Modernized exhibits, by their very design, trained visitors not to touch by placing objects in vitrines, behind glass, and out of reach. ${ }^{143}$ Still,

\footnotetext{
${ }^{140}$ Classen, "Touch in the Museum," in Classen, The Book of Touch, 281-83.

${ }^{141}$ Classen, Constance. "Touch in the Museum" in The Book of Touch, 282.

${ }^{142}$ Classen, Constance. "Touch in the Museum" in The Book of Touch, 282.

${ }^{143}$ Classen, Constance. "Touch in the Museum" in The Book of Touch, 260-62, 282.
} 
current-day exhibitions mostly relegate non-visual experiencing of art to the education department.

So how should we, now, as modern museum-goers behave? Carmen once told me that he, while leading a tour at the Vancouver Art Gallery, suggested to his group that they all lie down on the floor and experience the art from a different perspective. Of course, the security guards were concerned and moved in to disrupt the experiment...until they noticed he was blind. Then they stopped...and slowly backed away. Carmen's friends later told him the guards acted confused, as if they did not know how to handle him or the situation. Ah, the layers of interpretation that this action speaks for institutional control, stigma of disability yet fear of offending, and the power structures within it all.

\section{Museum engagement: a case study}

Upon remembering a visit to the Milwaukee Art Museum and being invited to engage with Carl Andre's "144 Pieces of Zinc," Debra Brehmer writes about the paradoxical and changing nature of museum engagement. She recognizes the opportunities to better connect with art works and how these interactions can strengthen one's memory of an art work, but also warns of the slippery slope into kitchiness and gimics like \#museumselfieday. It is through critical engagement that $L K I T$ aims to involve visitors, rather than the realm of said \#selfies.

Referring to the Andre piece referenced above, Brehmer shares,

"I walk across it because I like how it generates a little current of guilt. No matter how many times my heels click on its gray metal surface, it feels disconcerting. Andre makes us question our museum behavior. He entreats us to look down and feel a sense of contact with the floor and 
materiality of the piece; he also gives us a small surround or enclosure in which to stand and take in the rest of the room. When we stand on an Andre piece, the art defines the self. We have boundaries and a new perspective, a manifestation of place. It becomes apparent that everything we view is in relationship to the physicality and sensory limits of the self." 144

It would be fantastic if Brehmer, or other critical thinkers, might write such a response after experiencing some of the art objects included in our tactile engagement project. Such responses will be sought after tactile permissions have been arranged from Papalia's conversations with the artists.

\section{Concluding thoughts}

So where do we go from here? Tactility can enhance individuals' cognitive and aesthetic understanding of art objects, but conservation concerns limit what may be touched. Perhaps there is a middle ground, a place of inclusive dialogue in which certain objects may be open for tactile access ${ }^{145}$ by permission of their creator. Public art already fills some of this space, especially for outdoor sculptural works. But what of the art works inside the museum? That nascent, growing opportunity for access begins with Papalia's conversations and questioning and the subsequent precedents spurred by Let's Keep in Touch.

\footnotetext{
${ }^{144}$ Brehmer, Debra. "Carl Andre, Museum Etiquette, and Me." Hyperallergic. May 31, 2016. http://hyperallergic.com/302136/carl-andre-museum-etiquette-and-me/?ref=featured.

${ }^{145}$ There is an excellent resource of articles about tactile access in museum accessibility in a special edition of Disability Studies Quarterly, vol 33, no 3. I have summarized a number of the opinions expressed, but do not have sufficient space to cover all of them here. Included are articles by Carmen Papalia, Georgina Kleege, and Amanda Cachia, among others. "Special Issue: Museum Experience and Blindness." Disability Studies Quarterly 33, no. 3 (2013).
} 


\section{CONCLUSION}

\section{CHAPTER FIVE: COMING BACK AROUND TO LET'S KEEP IN TOUCH}

\section{Introduction}

The concluding chapter will first present a selection of recent projects involving tactility but not Papalia, in order to see comparisons in each to Let's Keep in Touch. Secondly, an annotated selected exhibition history of Carmen Papalia will serve as a supplement to the larger paper for context and details about the artist's relevant project history. Lastly, further details of $L K I T$ and future directions of the project and its corresponding research will be delineated. Supplemental documentation for the project, such as the list of selected artists and Carmen's letter to the artists will be included.

Selected comparative exhibition history of projects involving tactility In addition to instances of public art ${ }^{146}$ and individual museum touch tours, there have been a few recent instances of exhibitions which have sought and are

\footnotetext{
${ }^{146}$ The discussion of public art is complex and space does not allow for a reasonably sufficient treatment here. However, the relation of public art and tactile access is a connection that I would like to explore in the future research for this project.
} 
seeking to explore the nature of tactility in audience engagement. The following annotated exhibition history aims to provide examples relevant to Let's Keep in Touch, in the areas of technology and design, tactile aesthetics and tactile methodology, multisensorial experiencing of art, and tactile interaction with craft.

- Touch Me: Design and Sensation, Victoria and Albert Museum, London, UK. June 16-August 28, 2008. Curators: Luren Parker, Curator of Contemporary Programs, V\&A; and Hugh Aldersey-Williams, freelance writer and independent curator.

The exhibition focused on the confluence of art and science, design and craft, in an attempt to facilitate touch in a museum setting. The exhibition was highly interactive, but leaned in the direction of responsive technology and design. Several of the interactive, technology-based works responded to visitors as they entered the space. This exhibition is less of a parallel to $L K I T$, in its heavy use of technology and design, but rather serves as an example of an alternative direction of tactility in museums (that of science-focused) in contrast to the manual-based approach of LKIT.

For further information: http://www.hughalderseywilliams.com/exhib-touchme

- The Levity, the Gravity, Kadist Art Foundation, San Francisco, CA. January 16, 2016. Curators/Collaborators: Fayen Ke-Xiao d'Evie, artist, Australia-based; and Georgina Kleege, Professor of English, UC Berkeley. 
D'Evie and Kleege spent a week at the Kadist Art Foundation observing and studying a selected set of art objects for their tactile qualities. It was during this process that Kleege developed her set of criteria for ways of touching. The culmination of the week was a public event which included a performance by d'Evie and a touch tour lecture by Kleege, in which she described each object as she touched its components. Conversations with Kleege by both Papalia and Mashburn have significantly impacted the course of planning Let's Keep in Touch.

For further information: https://fayendevie.net/the-levity-the-gravity/

- Sweet Gongs Vibrating, San Diego Art Institute, San Diego, CA. March 26-May 28, 2016. Curator: Amanda Cachia Amanda Cachia was one of the first curators to include Papalia's work in her thesis exhibition in 2012, What Can a Body Do?, Haverford College, Pennsylvania. This most recent exhibition, Sweet Gongs Vibrating, focuses on multi-sensorial experiencing of art objects to activate alternative narratives, that of sound, touch, smell, and taste, as well as sight. Upon conversations with Cachia about this show, she mentioned the challenges of providing interpretation and instructions to visitors in regard to how to interact with the art. She did not want to overpower them with information so that they could interact freely, but noted the importance of keeping the art objects safe and unbroken in the process. 
- Touch: Interactive Craft, Arrowmont School of Arts and Crafts, Gatlinburg, TN. January 16 - March 11, 2016. Juror: Emily Zilber, Ronald L. and Anita C. Wornick Curator of Contemporary Decorative Arts, Museum of Fine Arts, Boston

This exhibition featured contemporary craft objects which gain significance by the visitor's touch. The show tackled the topic of craft objects as having a dual traditional purpose of functionality and also aesthetic value, and sought to break past typical gallery rules of passive viewing. This exhibition draws an interesting parallel to Let's Keep in Touch, in its inclusion of contemporary craft, and LKITs singular installation piece by Warzecha, ${ }^{147}$ contemporary craft artist. Conversations with Warzecha about the dual yet conflicting function of ceramics as functional yet aesthetically pleasing and fragile have led to a proposal being submitted for a presentation on the topic at NCECA 2017.

What makes Let's Keep in Touch different from these cited relevant examples? It operates on multiple levels in its combination of activism through social practice and curatorial practice and exhibition making. By having the project center around Papalia's conversations with the other artists, LKIT moves past being a static exhibition of objects and becomes a set of living interactions (the conversations) aimed to impact the experiencing of art objects in the future. It is this active vitality of its composition that makes the project a dynamic,

\footnotetext{
${ }^{147}$ Artist Christina Warzecha's work has a tie-in to ideas of Emily Zilber, as she was her research intern in 2015.
} 
developing being. It is the participation of all (Papalia, artists, future visitors, curator) involved that makes it function.

\section{Carmen Papalia: exhibition history and context}

In order to more fully understand Papalia's thinking in the proposal of Let's Keep in Touch, we must consider it in the context of his earlier and concurrent works. In contemplating Carmen Papalia's exhibition history and his mindful socially engaged practice, it is interesting to think, Carmen takes visual art and makes it non-visual. "Papalia's practice began in earnest when he lost his sight, but his artistic objectives speak to something that transcends the fact of his physiological nature and the devices used to negotiate it. He seeks to sensitize people to the power of perception and its potential for reshaping and enhancing one's relationship to the world." ${ }^{148}$ Each of the following projects exemplify this aim and successfully realize it.

Papalia's selected projects fall under three headings: mobility devices, participatory interventions led by the artist, and conversations. The mobility device projects function as performance of disability, and the interventions and conversations function as participatory open dialogues. The following annotated listing of projects should serve as a helpful reference to the larger discussions of the thesis.

\footnotetext{
${ }^{148}$ Krantz, Georgia. "How Do You See a Museum with Your Eyes Closed?" Guggenheim. April 29, 2014. https://www.guggenheim.org/blogs/checklist/how-do-you-see-a-museum-with-youreyes-closed.
} 


\section{Mobility Devices}

In these projects, Papalia makes use of alternative objects for mobility and orientation, the use of which becomes a performative act.

"Disabled", n.d.

This early work is worth noting in the progression of Papalia's work. I have only seen it documented in a personal slideshow on Papalia's iPad. The project involved a friend of Papalia's wearing a large signboard which said "disabled" on it, and going about his daily activities such as grocery shopping and riding public transportation. The sign served a dual purpose: it made everyday tasks more difficult to execute, as its physical size made it hard to maneuver. Also, it drew public attention to the individual and the word on the sign, "disabled," in an aim to provoke thought and show the barriers in place which hinder those with impairments.

I see Papalia's performance of a personal politics emerging in this work, through the prescribed performance of his friend. Also, I see him working out considerations of street performance here as well.

Long Cane, Vancouver, BC. 2009- 2012

The Long Cane has been frequently referenced in the thesis. It is the earliest example of Papalia's direct use of an altered mobility device. He purchased several standard canes, took them apart, and reassembled them into a single, foldable, extra-long, $15 \mathrm{ft}$. (and longer in later performances) cane. He 
then walked the sidewalks of his hometown, Vancouver, BC, using the cane. Its development was a reaction to strangers being overly helpful and making assumptions about his abilities, and also a reaction against the institutionalization of functioning of the blind (i.e. being prescribed a certain way to function in the world, by use of a white cane which symbolically and institutionally marked him). Papalia then videotaped the reactions of those around him as he walked and moved the cane. He has said of this work that he wanted to get into other people's space and create an exaggerated presence in which he would decide and create how he held space. I see this as Papalia's earliest performance of disability.

For video of the Long Cane, please see: https://vimeo.com/110540866

Mobility Device (marching band), ${ }^{149}$ Grand Central Art Center, Santa Ana, CA. June 2013

This performance is one of Carmen's most colorful and playful. In a project through the Grand Central Art Center in Santa Ana, he worked with The Great Centurion Marching Band from Century High School in Santa Ana. Papalia wandered on foot through the host city (with which he was unfamiliar), with the marching band following him. He did not use a cane, rather, he used the auditory cues from the band to tell him about his surroundings. For instance, the band's tempo mimicked the pace of Papalia's steps, and the tune played certain notes to indicate obstacles, or a physical step up or down in the artist's path.

\footnotetext{
${ }^{149}$ For an interesting article about this piece, see: Tracey, Emma. "'I Ditched My Cane for a Marching Band'." BBC News. March 09, 2015. http://www.bbc.com/news/blogs-ouch-31749643.
} 
Besides the playfulness and curiosity exuded by this piece, I also see it as a precursor to his 'blind field study' walks to come. Here, Papalia is leading the band, and their cues assist him in leading them. In the eyes-closed walks of the 'blind field study,' Papalia takes the full onus of leadership, as he brings back the cane but independently leads entire groups in a line behind him.

To hear Papalia talk about the work and to watch the performance, see: https://www.youtube.com/watch?v=c687G5ZdRxw

Sound Cane, Olin College, Needham, MA. May 2016

I had the privilege of joining Carmen on a visit to Olin College in Needham, MA. It is there that engineering students, under the supervision of faculty member and design innovator Sara Hendren ${ }^{150}$, are working with Papalia to create an acoustic mobility device, which has now been dubbed, the "sound cane..151 According to Papalia, after completing a micro-residency, taking the students on an eyes-closed walk, and talking extensively with them, the students devised a list of possible options for a creatively engineered device. The winner was the "sound cane," a handmade cane which has a microphone wire piped through it, with the tip of the wire at the end of the cane touching the ground. The cane is wired into a portable amplification box which is equipped with USB

\footnotetext{
${ }^{150}$ Sara Hendren is also behind the site, Abler, and is an innovator in new thinking about assistive technology design.

${ }^{151}$ Another instance of sound being used for mobility and for gathering information about one's surroundings is Daniel Kish's use of echolocation, a technique which he has pioneered in human use and now shares with others. Kish is the founder of World Foundation for the Blind. For further information, please see: "Blindness No Obstacle To Those With Sharp Ears." NPR. March 03, 2011. http://www.npr.org/2011/03/13/134425825/human-echolocation-using-sound-to-see. And Miller, Lulu, Alix Spiegel, and Hanna Rosen. "How to Become Batman." NPR. January 23, 2015. http://www.npr.org/programs/invisibilia/378577902/how-to-become-batman.
} 
speakers and guitar pedals. It is through this box that the sound emits through the speakers and may be distorted with different settings of the guitar pedals. The effects are quite performative. I had the joy of watching Carmen and Sam, one of the students, test out the newly constructed device on differently textured surfaces, much to the delighted curiosity of other students in the library. The only thing lacking in the functionality was the ability to record and loop sounds in layers for performance and to create sound compositions. Carmen and Sam proceeded later that week to Toronto to present the "sound cane" at a conference, where they successfully gave a live performance to the assembled crowd. This project may be considered in light of James Gibson's concept of an epicritical vibrissa. Yi-Fu Tuan describes the concept as "our knack of telling small variations in the roughness of the sidewalk pavement by simply trailing a stick over it. Most surprising is the way we feel the texture, not at the area of contact between hand and stick, but at the end of the stick, as though it were an anatomical extension of ourself." ${ }^{152}$ I would argue that the 'sound cane' is a further extension of this epicritical vibrissa, in that it takes these tactile observations of variation in surface texture and transfers them into sound. Then, as one step further, this sound is amplified to share with a larger audience than just the singular tactile examiner. In this way, the non-visual yet multisensorial exploration becomes a performed action and a shared experience.

Precedents for such an instrument have been set in the late 60 's/early 70 's in the form of the Nurion laser cane, one of which is housed here in

152 Gibson, James J. The Senses Considered as Perceptual Systems. Boston: Houghton Mifflin, 1966. In Tuan, Yi-Fu. "The Pleasures of Touch." In The Book of Touch, edited by Constance Classen. Oxford: Berg, 2005. 
Louisville in the museum of the American Printing House for the Blind. This cane by Nazir Ali was designed to use lasers to transfer visual cues into tactile and audio feedback. ${ }^{153}$ The cane had embedded lasers at three different levels to detect at three different angles and levels, obstacles in one's path. As the ambulator approached an obstacle detected by the laser(s), the cane had the option to beep and/or vibrate with increasing audio pitch or haptic intensity as the walker drew closer to the obstacle. Carmen's 'sound cane' unknowingly builds upon the history and background of the laser cane, all while taking the functioning of the cane into a new realm of performative action. In this way, the use of the cane becomes a socially engaged action and transforms a device originally meant for disability referencing into an instrument for sharing of nonvisual experiences.

Participatory interventions led by the artist

Blind Field Shuttle, Cantor Fitzgerald Gallery, Haverford College, Haverford, PA. 2012.

Repeated multiple times in multiple locations with varying audiences, such as: Portland Farmers Market (OR), High Line (NYC), Olin College (Needham, MA) At this point, the Blind Field Shuttle is the most well known of Papalia's works. In this performative, participatory gesture, Papalia leads a group of people

${ }^{153}$ Smith, Claire Furia. "Inventor Sticking to His Vision: A High-tech Cane for the Blind LaserCane's Developers Navigate around Obstacles of Their Own." Philly.com. January 06, 2003. http://articles.philly.com/2003-01-06/business/25468751_1_blind-people-smallbusinesses-nazir-ali. 
(usually no more than 45-50) in a line behind him. The individuals behind him each hold the shoulder of the person in front of them. Everyone is required to close their eyes. Using his cane, Papalia leads the group along a route that he has mapped out in advance, usually for about 30 minutes duration. At the end of the route, which sometimes lands back at the starting point, and sometimes at a new place entirely, Papalia instructs the group to open their eyes on the count of three. The experience is meant to heighten nonvisual awareness of one's environment.

When I was visiting with Carmen this spring (2016), he asked if I would be interested in going on an eyes closed walk. I was excited for the opportunity. So, at the end of the day after our meetings at Olin College, Carmen took me on the walk he had previously led for the Olin students. I must admit, there were times when we were near the road and I could hear the cars passing, I was a bit apprehensive. But, I thought, Carmen navigates for himself all the time, he's just as able to navigate for the both of us. It was a wonderfully immersive experience, and like other participants have noted, I found myself listening for audio cues, for instance we used the sound of a nearby sports practice to ground our bearings. I was also more aware of the breeze on my skin and especially the texture of the ground beneath my feet. As I am already hypersensitive to fragrances due to a chemical sensitivity, I also found myself using olfactory clues as well. Overall, without the distractions of visual overstimulation, the experience allowed me to focus more on my thoughts, nonvisual observations, and conversation with Carmen. As we took a wrong turn along the way, we pooled 
our observations for problem solving strategies. Upon reopening my eyes, there was quite a sensory overload, which made me realize how much I tune out from especially my sense of touch in the everyday.

A truly immersive experience, Papalia successfully places the audience in the role of participant, and into the space of learning nonvisually -- by doing. Not by reading about it, not by imagining, but by doing. Papalia accurately and truly shares ideas with others in the most effective way in such a short period of time - by active participation. He engages others to learn -- it is no wonder he longs for them (and him as the artist) to engage with art objects, too. And it is no wonder that he unassumingly describes himself as a nonvisual learner, for collective learning is at the heart of his practice.

For a video of the Blind Field Shuttle on the High Line, see:

https://vimeo.com/78862660

See for Yourself, The Whitney Museum of American Art, NYC. June 2013

Situated at the Whitney, Papalia organized this project to be somewhat self-sufficient. Instead of leading tours himself, he collaborated with Whitney staff members to serve as guides to visitors (who kept their eyes closed during the tour). The staff guides gave conceptual, subjective, nonvisual tours ${ }^{154}$ to the visitors, describing everything they saw as they moved through the museum, be it the art, the architecture, or other patrons. I see this project as taking the Blind

\footnotetext{
${ }^{154}$ The Whitney Museum currently offers monthly touch and verbal description tours, but these are still limited to special programming under "access" for visitors with blind and low vision, set to take place in the morning before the museum opens. See:

http://whitney.org/Events/VerbalTouchTourAugust2016
} 
Field Shuttle and moving it inside the museum. It is the beginning of Papalia's application of access projects and nonvisual learning to museum-based institutional critique. It also serves as an example of Papalia's desire to create situations which can function without his presence.

For more information and to watch this project in action, please see: http://whitney.org/WatchAndListen?play_id=900

The Touchy Subject, The Guggenheim Museum, NYC. November 2013 In this project at the Guggenheim, museum educators, much like the staff at the Whitney, organized behind Papalia's plans and premise. They guided eyes-closed visitors around the museum, inviting them to touch the architecture and its subtle details and large forms. They also provided to the visitors materials which had been used to make some of the art works on display, for instance an aluminum sheet and a patterned linoleum roller. The whole experience served to sensitize the visitors to the nonvisual cues and details surrounding them in the environment, which made them feel all the more connected to the artworks within the museum once they opened their eyes. Here, Carmen's exploration of facilitating tactile access is emerging richly. For a video about this project please see: https://www.guggenheim.org/video/thetouchy-subject

And:

https://www.guggenheim.org/blogs/checklist/how-do-you-see-a-museum-withyour-eyes-closed 
Ear-Cleaning Tour / For Your Ears Only, MoMA, NYC. November 2013

Just as the Guggenheim tours sensitized visitors to their tactile sense, the tours at MoMA sensitized visitors to auditory clues within soundscapes. Here, Papalia himself led a group of visitors wearing earplugs to specific locations within the museum, and then instructed them to remove the earplugs. The resulting sensitivity allowed the individuals to hear the soundscapes more clearly and be more attuned to them.

For further info: http://artsinitiative.columbia.edu/events/artist-workshop-earcleaning-tour-carmen-papalia

It is interesting to note the development of how, systematically, Papalia investigated participatory projects without and within museum settings, one sense at a time. First he conducted the tour format outside the museum with Blind Field Shuttle, then took it inside with See for Yourself. Then, he targeted sensitization of a singular sense at a time with The Touchy Subject and EarCleaning Tour. It is an excellent process for working out methods and allowing visitors to focus. I think part of the brilliance in Papalia's work is its simplicity to allow the audience the range to think more deeply and conceptually.

\section{Conversations}

Much like Papalia has pursued the 'tour' format in his participatory works, and alternative anti-institutional yet creative means of mobility (thus activating the 
performance of disability), he also has created a common thread of using conversation as a tool to learn from others and share his ideas in order to further collective understanding, awareness, and problem-solving about access. Since each of the 'conversation' pieces have had significant treatment earlier in the thesis document, no repetitive descriptions will be given here. It is suffice to say that conversation is one of Papalia's most successful tools of conveying information and learning in his own practice. His kind and unassuming nature eases the criticality of the content, and these conversations serve as inclusive activism for accessibility.

Temporary Services: A Conversation with Carmen Papalia. 2012

Please see Chapter 1 for a lengthy description and discussion.

The New Access Consortium Presents: A Collective Audit of the Vancouver Art Gallery, Gallery Gachet, Vancouver, BC, Canada. ${ }^{155}$ November 8, 2015 -

December 13, 2015

Please see Chapter 2 for description and discussion.

Let's Keep in Touch, Gallery X, Schneider Hall, University of Louisville, Louisville, KY. August 2016

Please see the Introduction to the thesis for a full discussion of the current project.

${ }^{155}$ Please see Addendum A for a copy of Carmen's letter. 
"Let's Keep in Touch": future directions

Thesis research and critical discourse

Time limitations and paper length do not allow for the full research and discussion of Let's Keep in Touch and its implications. However, the following areas are on the docket for future, more in-depth research that I plan to undertake in the continuation of this project: institutional critique, disability studies, further connections in SEA, public art in relation to tactile access, and specifics of conservation concerns. Though happy with the presentation of tactility research so far, I would also like to continue it as well, as it is quite possibly my favorite area covered in this paper.

\section{The project}

As described in the introduction, plans are underway for future iterations of Let's Keep in Touch to include objects of other media with gradiating levels of tactility. Additionally, the project is in a discussion phase with institutions internationally to facilitate potential exhibitions in museum settings, using permanent collection holdings as tactile objects.

Tactile access to two-dimensional works: input from Carol Mode, painter As part of my research, I have sought feedback from other artists in regard to tactile access to their works. Specifically, in thinking ahead for 2-D works of 
art being haptically investigated by visitors, I sought input from abstract painter, Carol Mode, whose works tempt touch with their subtly layered textures.

Painter Carol Mode, of Nashville, represented by Sandler Hudson Gallery in Atlanta, creates acrylic paintings of organic and geometric shapes in which she removes and adds layers and patterns of paint. She uses methods of both taping off areas and scraping down sections. Together, these techniques produce a finely layered surface, one that I am interested in touching and feel others could benefit from tactile access to as well. In my studio visits with Carol, I have often noticed her running her hands along the surface of her works. She describes the concepts behind her methods as,

"In my recent paintings I am looking for spaces in the mind, mental maps of visual information. The method I use resembles a building process with uncovering, excavating and rebuilding the surface. I am interested in exploring possibilities of image repletion in that they represent slight changes in a moment of time. It is the reorganizing of the imagery that becomes the challenge, something like a chess game. I use abstraction as a vehicle for the continuous discovery of new forms in space."156

I asked her how she felt about her paintings being made available for a haptic

experience. The following is a selection from her response:

"I have often thought about my own desire to get close and closer to expressive paintings which have strong textural surfaces. The smoothness, the jagged edges, and layers and layers of paint and other materials on surfaces trigger my own desire to 'touch' and 'feel'. Although I may long to touch and become part of the painting, I believe that the layering of paint makes the process and method even more mysterious and remarkable. Traces of this layering remain present in my finished work as intentionally tactile markers. During my own exhibitions I often notice the public inching closer, imaginatively touching the surface of my paintings. After waiting to see how close they actually go, I may ask the viewers about their need to approach and touch - to understand how it adds to their experience. Their answers don't conform to a uniform standard, so 'visualization' is not entirely the cause. The actual 'touch' is

${ }^{156}$ Carol Mode artist statement, courtesy Sandler Hudson gallery. 
the experience. It appears that they sense my process of 'adding and subtraction' to an art work, reinventing it and allowing for them to reach their own conclusions about the process." 157

Mode, here, sees even an imaginative 'touch' as furthering the understanding and investigation of the artwork. Just imagine what information an actual physical touch might yield. Clearly, though, she is not exactly comfortable with the idea of multiple individuals running their hands along the surface of her paintings, and is happier with a conceptual 'touching' of the work.

I admit, the conservation concerns make me a little nervous as well. But, in a conversation with Carmen, upon discussing this topic, he posed an interesting question: what if conservation efforts were part of the art experience process? What if the process of tactile experiencing of a work included the steps of both touching by the audience and 'retouching' by the conservator?

The implications for the institution are monetarily costly and time-intensive. The assumption is that few institutions would support such a process. However, that brings us back to Papalia's curious yet accurately probing questioning of assumptions and his push for a paradigm shift in museum engagement. It is his willingness to ask these sorts of progressive questions that will start the conversation for change in the first place. And that first visionary step is the most critical one.

\footnotetext{
${ }^{157}$ Mode, Carol. "Comment/tactile Access to 2-D Art." E-mail to Whitney Mashburn. June 11, 2016.
} 


\section{REFERENCES}

"About." Gallery Gachet. http://gachet.org/about/.

"About - City Museum." City Museum. http://www.citymuseum.org/visit/about/.

"About PTM - Please Touch Museum." Please Touch Museum.

http://www.pleasetouchmuseum.org/about/about-ptm/.

Alberro, Alexander, and Blake Stimson, eds. Institutional Critique: An Anthology of Artists' Writings. Cambridge, MA: MIT Press, 2011.

"Arts Initiative Columbia University Experience, Engage, Create." Artist Workshop: Ear-Cleaning Tour with Carmen Papalia. November 15, 2013. http://artsinitiative.columbia.edu/events/artist-workshop-ear-cleaning-tourcarmen-papalia.

Bachmann, Konstanze. Conservation Concerns: A Guide for Collectors and Curators. New York: Cooper-Hewitt National Museum of Design, Smithsonian Institution, 1992.

Becker, Carol. The Subversive Imagination: Artists, Society, and Social Responsibility. New York: Routledge, 1994.

Berenson, Florentine Painters of the Renaissance, 1906.

Bishop, Claire. Artificial Hells: Participatory Art and the Politics of Spectatorship. London: Verso Books, 2012. 
Bishop, Claire, ed. Participation. London: Whitechapel, 2006.

Black, Graham. The Engaging Museum: Developing Museums for Visitor Involvement. London: Routledge, 2005.

"Blindness No Obstacle To Those With Sharp Ears." NPR. March 03, 2011. http://www.npr.org/2011/03/13/134425825/human-echolocation-usingsound-to-see.

Bloomer, Carolyn M. Principles of Visual Perception. New York: Van Nostrand Reinhold, 1976.

Bourriaud, Nicolas. Relational Aesthetics. Dijon: Les Presses Du Réel, 2009. Brehmer, Debra. "Carl Andre, Museum Etiquette, and Me." Hyperallergic. May 31, 2016. http://hyperallergic.com/302136/carl-andre-museum-etiquetteand-me/?ref=featured.

Cachia, Amanda. "Disability, Curating, and the Educational Turn: The Contemporary Condition of Access in the Museum." OnCurating.org : After the Turn: Art Education beyond the Museum, no. 24 (December 2014): 51-66. http://www.on-curating.org/index.php/issue-24-reader/disabilitycurating-and-the-educational-turn-the-contemporary-condition-of-accessin-the-museum.html\#.V1c_PJODGkp.

"Carmen Papalia, See for Yourself." Whitney Museum of American Art. June 7, 2013. http://whitney.org/Events/SeeForYourself.

Carr, David. A Place Not a Place: Reflection and Possibility in Museums and Libraries. Lanham, MD: Rowman \& Littlefield Publishers, 2006. 
Catlin-Legutko, Cinnamon, and Stacy Klingler. The Small Museum Toolkit.

Lanham, MD: AltaMira Press, 2012.

Chatterjee, Helen, Sally MacDonald, David Prytherch, and Guy Noble. Touch in Museums: Policy and Practice in Object Handling. Oxford: Berg, 2008.

Classen, Constance. The Book of Touch. Oxford: Berg, 2005.

Decker, Juilee. Engagement and Access: Innovative Approaches for Museums.

Dent, Peter. Sculpture and Touch. Farnham: Ashgate Publishing Limited, 2014. Design like You Give a Damn: Architectural Responses to Humanitarian Crises. London: Thames \& Hudson, 2006.

D'Evie, Fayen, and Georgina Kleege. "Hand(s) On: The Levity, The Gravity." FAYEN KEXIAO DEVIE. January 02, 2016. https://fayendevie.net/thelevity-the-gravity/.

Dodd, Jocelyn, Ceri Jones, Debbie Jolly, and Richard Sandell. "Disability Reframed: Challenging Visitor Perceptions in the Museum." In Representing Disability: Activism and Agency in the Museum, edited by Richard Sandell, Jocelyn Dodd, and Rosemarie Garland-Thomson. London: Routledge, 2010.

Driscoll, Rosalyn. "Pictorial essay B: Playing with fire" in Dent, Peter, ed. Sculpture and Touch. Farnham: Ashgate Publishing Limited, 2014.

Dubin, Steven C. Displays of Power: Memory and Amnesia in the American Museum. New York: New York University Press, 1999.

Dziekan, Vince. Virtuality and the Art of Exhibition: Curatorial Design for the Multimedial Museum. Bristol, UK: Intellect, 2012. 
"The Elizabeth Morse Touch Gallery." The Art Institute of Chicago. http://www.artic.edu/exhibition/elizabeth-morse-touch-gallery.

Fletcher, Harrell. "4.26.16." Harrell Fletcher. April 26, 2016. http://www.harrellfletcher.com/?cat=33.

Fletcher, Harrell, and Miranda July. "Learning To Love You More." Learning To Love You More. 2009. http://www.learningtoloveyoumore.com/.

Fraser, Andrea. "From the Critique of Institutions to an Institution of Critique." In Institutional Critique: An Anthology of Artists' Writings, edited by Alexander Alberro and Blake Stimson. Cambridge, MA: MIT Press, 2011. (originally published in Artforum 44, no.1(September 2005): 278-283, 332.)

Fried, Laura. "Some Alternatives to Institutional Critique." ART21 Magazine. April 30, 2010. http://blog.art21.org/2010/04/30/some-alternatives-toinstitutional-critique-2/\#.V0p7JJODGko.

Fuery, Patrick, and Kelli Fuery. Visual Cultures and Critical Theory. London: Arnold, 2003.

Gaines, Charles, Lisa Gabrielle. Mark, Maria Lind, Marina Abramovic, Ólafur Elíasson, and Dan Graham. Akademie X: Lessons Tutors in Art. London: Phaidon Press, 2014.

Gallace, Alberto, and Charles Spence. "A Memory for Touch: The Cognitive Psychology of Tactile Memory." In Touch in Museums, 253-60. Oxford: Berg, 2008. 
Gallace, Alberto, and Charles Spence. "Tactile Aesthetics: Towards a Definition of Its Characteristics and Neural Correlates." Social Semiotics 21, no. 4 (2011): 569-89. doi:10.1080/10350330.2011.591998.

Gallace, Alberto, and Charles Spence. "The Neglected Power of Touch: What the Cognitive Neurosciences Can Tell Us about the Importance of Touch in Artistic Communication." In Sculpture and Touch, by Peter Dent, 107-24. Farnham: Ashgate Publishing Limited, 2014.

Gibson, James J. The Senses Considered as Perceptual Systems. Boston: Houghton Mifflin, 1966. In Tuan, Yi-Fu. "The Pleasures of Touch." In The Book of Touch, edited by Constance Classen. Oxford: Berg, 2005.

Gopnik, Adam. "Feel Me." The New Yorker, May 09, 2016. http://www.newyorker.com/magazine/2016/05/16/what-the-science-oftouch-says-about-us.

Grant, Daniel. "Social Practice Degrees Take Art to a Communal Level." The New York Times. February 06, 2016. http://www.nytimes.com/2016/02/07/education/edlife/social-practicedegrees-take-art-to-a-communal-level.html? $r=0$.

Green, Alison. "Citizen Artists: Group Material." Afterall • Journal • Issue 26. Spring 2011. http://www.afterall.org/journal/issue.26/citizen-artists-groupmaterial.

Group Material (Doug Ashford, Julie Ault, and Felix Gonzalez-Torres). "On Democracy." In Participation, edited by Claire Bishop, 135-37. London: Whitechapel, 2006. 
Guattari, Félix, The three ecologies, London: Athlone Press, 2001.

Guest, S., Catmur, C., Lloyd, D. and Spence, C. 'Audiotactile interactions in roughness perception', Experimental Brain Research 2002, 146:161-71.

Helguera, Pablo. Education for Socially Engaged Art: A Materials and Techniques Handbook. New York: Jorge Pinto Books, 2011.

Hooke, Robert. In Arnold, K. (2003), “Skulls, Mummies and Unicorns' Horns: Medicinal Chemistry in Early English Museums," in R.G.W. Anderson, M.L. Caygill, A.G. MacGegor and L. Syson (eds) Enlightening the British: Knowledge, Discovery and the Museum in the Eighteenth Century, London: The British Museum Press. In Classen, Constance, "Touch in the Museum" In The Book of Touch, edited by Constance Classen. Oxford: Berg, 2005.

Jackson, Shannon. "Performance, Aesthetics, and Support." in Jackson, Shannon, ed. Social Works: Performing Art, Supporting Publics. New York: Routledge, 2011.

Jackson, Shannon, ed. Social Works: Performing Art, Supporting Publics. New York: Routledge, 2011.

Kadist Art Foundation. "Touch Tour by Georgina Kleege with Work by Adrian Wong." January 2016. https://vimeo.com/154934219.

Keeler, S. P., and Juliana Dreiver. Service Media: Is It "Public Art" or Is It Art in Public Space?: A Collection of Essays. Chicago: Green Lantern Press, 2013. 
Kester, Grant H. Conversation Pieces: Community and Communication in Modern Art. Berkeley: University of California Press, 2004, 70-71.

Kleege, Georgina. Sight Unseen. New Haven, CT: Yale University Press, 1999. Kleege, Georgina. "Some Touching Thoughts and Wishful Thinking."DSQ Disability Studies Quarterly 33, no. 3 (2013). doi:10.18061/dsq.v33i3.3741.

Kleege, Georgina. "Whitney Mashburn Conversation with Georgina Kleege." Telephone interview by author. June 4, 2016.

Krantz, Georgia. "How Do You See a Museum with Your Eyes Closed?" Guggenheim. April 29, 2014. https://www.guggenheim.org/blogs/checklist/how-do-you-see-a-museumwith-your-eyes-closed.

Lars Bang Larsen. "Social Aesthetics // 1999." in Bishop, Claire, ed. Participation. London: Whitechapel, 2006.

Lippard, Lucy, and Adrian Piper. "Catalysis: An Interview with Adrian Piper."The Drama Review: TDR 16, no. 1 (1972): 76. doi:10.2307/1144734.

Marstine, Janet. New Museum Theory and Practice: An Introduction. Malden, MA: Blackwell, 2006.

Miller, Lulu, Alix Spiegel, and Hanna Rosen. "How to Become Batman." NPR. January 23, 2015. http://www.npr.org/programs/invisibilia/378577902/howto-become-batman.

Millett-Gallant, Ann. The Disabled Body in Contemporary Art. New York: Palgrave Macmillan, 2010. 
Mode, Carol. "Comment/tactile Access to 2-D Art." E-mail to Whitney Mashburn. June 11, 2016.

Monti, Francesca, and Suzanne Keene. Museums and Silent Objects: Designing Effective Exhibitions. Burlington, VT: Ashgate, 2013.

Nauert, Patricia, and Caroline M. Black. Fine Arts Insurance: A Handbook for Art Museums. Savannah? Ga.: Association of Art Museum Directors, 1979.

"The New Access Consortium Presents: A Collective Audit of the Vancouver Art Gallery." Gallery Gachet. November 2015. http://gachet.org/exhibitions/the-new-access-consortium-presents-acollective-audit-of-the-vancouver-art-gallery/.

Noordegraaf, Julia. Strategies of Display: Museum Presentation in Nineteenthand Twentieth-century Visual Culture. Rotterdam: Museum Boijmans Van Beuningen, 2004.

Norton, R.E., Herder's Aesthetics and the European Enlightenment, Ithaca, NY: Cornell University Press, 1990.

Nussbaumer, Linda L. Human Factors in the Built Environment. O'Sullivan, Lisa, and Julie Anderson. "Histories of Disability and Medicine." In Re-presenting Disability: Activism and Agency in the Museum, edited by Richard Sandell, Jocelyn Dodd, and Rosemarie Garland-Thomson. London: Routledge, 2010.

Papalia, "For a New Accessibility," 2016, to be published as chapter in a forthcoming anthology of disability studies.

Papalia, Carmen. "Re: Thesis." E-mail to Whitney Mashburn. March 31, 2016. 
Papalia, Carmen. Temporary Services with Carmen Papalia. Edited by Jen Delos Reyes. PSU Art and Social Practice Reference Points. Portland, OR: Publication Studio, 2013. http://a.nnotate.com/docs/2014-0512/QUc9qIW4/RP_1_TEMP_FINAL_REV.pdf.

Papalia, Carmen. "You Can Do It With Your Eyes Closed." ART21 Magazine. October 07, 2014. http://blog.art21.org/2014/10/07/you-can-do-it-withyour-eyes-closed/.

Plas, Els Van Der., Malu Halasa, and Marlous Willemsen. Creating Spaces of Freedom: Culture in Defiance. London: Saqi, 2002.

Rancière, Jacques. The Emancipated Spectator. London: Verso, 2009.

Raunig, Gerald, and Gene Ray, eds. Art and Contemporary Critical Practice: Reinventing Institutional Critique. London: MayFlyBooks, 2009.

Samuels, Jane. "The British Museum in Pentonville Prison." In Touch in Museums, 253-60. Oxford: Berg, 2008.

Sandell, Richard, Jocelyn Dodd, and Rosemarie Garland-Thomson. Representing Disability: Activism and Agency in the Museum. London: Routledge, 2010.

Satinsky, Abigail. "Essay." in Papalia, Carmen. Temporary Services with Carmen Papalia. Edited by Jen Delos Reyes. PSU Art and Social Practice Reference Points. Portland, OR: Publication Studio, 2013. http://a.nnotate.com/docs/2014-0512/QUc9qIW4/RP_1_TEMP_FINAL_REV.pdf. 
Schneider, Claire. More Love: Art, Politics, and Sharing since the 1990s. Chapel Hill, NC: Ackland Art Museum, The University of North Carolina at Chapel Hill, 2013.

Shakespeare, Tom. "The Social Model of Disability." In The Disability Studies Reader, edited by Lennard J. Davis. New York: Routledge, 1997.

Shore, Irma, and Beatrice Jacinto. Access to Art: A Museum Directory for Blind and Visually Impaired People. New York: American Foundation for the Blind, 1989.

Siebers, Tobin. Disability Aesthetics. Ann Arbor: University of Michigan Press, 2010.

Simon, Nina. The Participatory Museum. Museum 2.0, 2010.

Smith, Claire Furia. "Inventor Sticking to His Vision: A High-tech Cane for the Blind LaserCane's Developers Navigate around Obstacles of Their Own." Philly.com. January 06, 2003. http://articles.philly.com/2003-0106/business/25468751_1_blind-people-small-businesses-nazir-ali.

"Special Issue: Museum Experience and Blindness." Disability Studies Quarterly 33, no. 3 (2013).

Spence, Charles, and Alberto Gallace. "Making Sense of Touch." In Touch in Museums: Policy and Practice in Object Handling, by Helen Chatterjee, Sally MacDonald, David Prytherch, and Guy Noble, 21-40. Oxford: Berg, 2008.

Spence, C. and Zampini, M. 'Auditory contributions to multisensory product perception', Acta Acustica united with Acustica 92: 1009-25, 2006. 
Thaler, Lore, Wilson, Rosanna C. \& Gee, Bethany K. "Correlation between Vividness of Visual Imagery and Echolocation Ability in Sighted, EchoNaive People." Experimental Brain Research 232(6): 1915-1925, 2014. Tracey, Emma. "I Ditched My Cane for a Marching Band'." BBC News. March 09, 2015. http://www.bbc.com/news/blogs-ouch-31749643.

Vargas, Chris. "MOTHA: Mission Statement." Museum of Transgender Hirstory \& Art. October 2013. http://www.sfmotha.org/.

Villeneuve, Pat. From Periphery to Center: Art Museum Education in the 21st Century. Reston, VA: National Art Education Association, 2007.

"Visit the Tactile Dome | Exploratorium." Exploratorium Blog. August 01, 2014. http://www.exploratorium.edu/visit/west-gallery/tactile-dome.

Weil, Stephen Edward. Rethinking the Museum and Other Meditations. Washington: Smithsonian Institution Press, 1990.

Wexler, Alice, and Roger Cardinal. Art and Disability: The Social and Political Struggles Facing Education. New York: Palgrave Macmillan, 2009.

Wilson, Brent. The Quiet Evolution: Changing the Face of Arts Education. Los Angeles: Getty Education Institute for the Arts, 1997.

Zimmer, Robert, Janis Jeffries, and Mandayam Srinivasam. "Touch Technologies and Museum Access" in Touch in Museums: Policy and Practice in Object Handling. Edited by Helen Chatterjee. Oxford: Berg, 2008. 150-59. 


\section{APPENDICES}

\section{Supplementary Materials for Let's Keep in Touch Project abstract}

The project seeks to redefine museum engagement with art objects through consent of living artists for tactile access of their works. No loans will be needed, simply the written consent of the artist will be added to the respective museum object file of their work to create a precedent for future engagement.

The project process will consist of the artist, Carmen Papalia, contacting and having conversations with artists chosen by the curator, Whitney Mashburn. The group of chosen artists and their works will form a cohesive grouping and will not be limited to a single geographic locale. The exhibition will include a single tactile installation work, and will present the documentation of the project process, that of Papalia's conversations with the artists, and of the resulting changes made to object files for future museum engagement. The project aims to spur lasting changes and promote the exploration of multisensorial understanding of art objects by challenging current singularly visual biases.

Papalia's efforts are enriched by his relationship-building, which also serves as a means to deal with physical, cultural, and institutional barriers. He thus uses the tool of conversation to deconstruct these barriers, spur lasting 
changes, and promote the exploration of multisensorial understanding of art objects by challenging current singularly visual biases.

\section{Checklist of artists}

1. Michael Aurbach, b. 1952, Wichita, Kansas, USA. Lives and works in Nashville, TN.

https://aurbachsculpture.com

2. Tara Donovan, b. 1969, New York City, NY. Lives and works in Brooklyn, NY. http://www.pacegallery.com/artists/111/tara-donovan

3. Rosalyn Driscoll, b. 1949. Lives and works in Haydenville, MA. http://rosalyndriscoll.com/

4. Corey Patrick Dunlap, b. 1991, Birmingham, AL. Lives and works in San Diego and Los Angeles, CA. http://coreypatrickdunlap.com/

5. Khaled Jarrar, b. 1976 in Jenin, Palestine. Lives and works in Ramallah, Palestine.

http://www.ayyamgallery.com/artists/khaled-jarrar

6. Charles Ledray, b. 1960, in Seattle, WA. Lives and works in New York, NY. http://www.speronewestwater.com/artists/charles-ledray

7. Turiya Magadlela, b. 1978, Johannesburg, South Africa. Lives and works in Johannesburg. 
http://www.blankprojects.com/artists/turiya-magadlela/

8. Serge Alain Nitegeka, b. 1983, Johannesburg, South Africa. Lives and works in Johannesburg.

http://www.marianneboeskygallery.com/artists/serge-alain-nitegeka/works

9. Martin Puryear, b. 1941, Washington, D.C. Lives and works in New York's Hudson Valley.

http://www.matthewmarks.com/new-york/artists/martin-puryear/

10. Doris Salcedo, b. 1958, Bogotá, Colombia. Lives and works in Bogotá.

http://www.alexanderandbonin.com/artist/doris-salcedo

11. Chiharu Shiota, b. 1972, Osaka, Japan. Lives and works in Berlin, Germany. http://www.chiharu-shiota.com/en/

12. Lisa Sigal, b. 1962, Philadelphia, PA. Lives and works in Brooklyn, NY. http://lisasigal.net/

13. Laure Tixier, b. 1972, Clermont-Ferrand, France. Lives and works in Paris. http://www.galeriepolaris.com/artistes.php?id=2

14. Adriana Varejão, b. 1964, Rio de Janeiro, Brazil. Lives and works in Rio de Janeiro.

http://www.adrianavarejao.net/

15. Cayce Zavaglia, b. 1971, Valparaiso, IN. Lives and works in St. Louis, MO. http://www.caycezavaglia.com/

16. Fatiha Zemmouri, b. 1966, Casablanca, Morocco. Lives and works in Casablanca.

http://www.fatihazemmouri.com/ 
Papalia's approach letter to the artists

Dear artist,

I hope this finds you well and enjoying the day.

My name is Carmen Papalia and I am a social practice artist and nonvisual learner living in Vancouver.

I am writing to introduce myself and to ask if you might be interested in being involved in a new curatorial project that I am currently producing with my collaborator Whitney Mashburn.

The project, entitled Let's Keep in Touch, seeks to establish opportunities for tactile access to a number of contemporary works in order to set a precedent for critical tactile engagement / haptic criticism and tactile aesthetics—an emerging field that I have been contributing to in various ways over the last few years. I will begin by sharing a bit about my practice and will continue with a description of what Whitney and I have in mind!

First off, here is a link to an article that I wrote for Art21:

http://blog.art21.org/2014/10/07/you-can-do-it-with-your-eyes-closed/

It outlines the progression of my practice and includes photo and video documentation from a few of my projects-including the Touchy Subject, a series of eyes-closed touch tours that I conducted at the Guggenheim in 2013. The concept for Let's Keep in Touch began to take shape as I was developing The Touchy Subject—when I started to wonder about the various bodies of knowledge that might come to light if we, as a culture, were dedicated to 
exercising our nonvisual senses. Following this thread, I wondered about the artist's view (a position in which their hands are often in constant contact with a given material) and how the ways in which we commonly approach viewership seldom afford the viewer this intimate knowledge of the work.

These thoughts largely came about after conversations with my good friend and mentor Georgina Kleege, a fellow nonvisual learner who teaches English at the University of California at Berkeley.

Here is a short article by Georgina describing an experience in which she touched a set of sculptural maquettes by Matisse at the MoMA.

http://dsq-sds.org/article/view/3741/3284http://dsq-sds.org/article/view/3741/3284

In terms of Let's Keep in Touch, this is what Whitney and I are proposing: Whitney will curate a set of works by living artists and I will negotiate with each artist so their work may be touched by the viewer at some future point in time.

I will connect with each respective artist, sharing my experiential research regarding critical tactile engagement / haptic criticism and tactile aesthetics, so we may settle upon an agreement for tactile access to their selected work. Rather than negotiating for each work to be available for touch during the course of our exhibition, Whitney and I will focus on securing an opportunity for tactile engagement through an agreement with each selected artist and will find compelling ways to illustrate this exchange for the exhibition component of this project. If the work in question is currently held in a collection, we will begin a 
conversation with each respective institution so a plan for the infrastructure necessary for continued tactile engagement may be realized.

In developing the curatorial vision for this project, Whitney identified your work as lending itself especially well to the tactile sense.

Whitney and I are still in the process of establishing avenues to other work that we think might inform this project but have shared our plans with a select few and are happy to report that there is much enthusiasm for what we are proposing. That said, we both think your work will enrich this effort greatly and would love to find a way to work with you! If you would like to discuss what I have outlined in further detail please do be in touch, I would be happy to find some time to chat in the coming days / weeks. I am based in Vancouver and will be in town for just over a month before I leave again for projects.

My \# is 778.788 .1414

Take good care and looking forward to talking soon.

With much appreciation,

-Carmen Papalia

\section{Biography: Christina Warzecha}

Christina Warzecha is a studio artist with an MFA in Ceramics and Graduate Certificate in Museum Studies from Northern Illinois University, and a BA in Studio Art from Loyola University Chicago. Her professional museum interests and studio practice align in the interest of broadening the definition of 
contemporary craft and its role in the exhibition. She has exhibited work throughout the country, including the 2015 NCECA National Student Juried Exhibition where she received the second place graduate student award and the 2016 Midwestern Biennial at the Rockford Art Museum where she received the juror's choice award. She has received such professional opportunities as summer internships in 2015 at the Museum of Fine Arts Boston and in 2016 at the Kentucky Museum of Art and Craft in Louisville. Christina lives in Chicago, and is currently the gallery director at Rockford University and art preparator at the contemporary Chicago gallery Roots and Culture.

For further info, please see: http://christinawarzecha.com/

Julie Ault

Debra Bauder

John P. Begley

Amanda Cachia

Fayen d'Evie

Harrell Fletcher

Kristen Gresh

Micheal Hudson

Mary Jane Jacob

Susan Jarosi 


\section{Georgina Kleege}

Jen Mergel

Bob Mode

Carol Mode

Peter Morrin

Chris Reitz

Jamie Satcher

Yasmeen Siddiqui

Letter to Temporary Services from Carmen Papalia, 2012

Dear Temporary Services,

My name is Carmen Papalia and I am an artist and radical social worker living in Portland, Oregon. I have been making interactive experience-based work that creates the opportunity for productive conversation on the topic of access as it relates to public space, the Art institution and visual culture. I grew up in Vancouver, British Columbia where I co-founded a not-for-profit called the Memewar Arts and Publishing Society—an umbrella organization for an interdisciplinary publication called Memewar Magazine, a monthly reading series called the Short Line, a chapbook press called memePRESS, and a number of writing and publishing workshops for youth and adults. I didn't go to art school, but studied contemporary poetry and poetics during my undergrad-where I 
developed a critical eye and identified the subjects that I am interested in exploring in my work. My own personal struggle (I'm visually impaired) with regard to accessing things like print materials, public space and the institutional structure lead me to develop work that both encourages and problematizes accessibility - a practice that I have been devoted to for a year and a half now. It is my interest in exploring themes such as these that drew me to learning more about your work. I have to admit, since I was steeped, for years, in publishing and literary communities in Vancouver, I hadn't encountered the work of Temporary Services until I experienced a lecture by Deborah Stratman in 2011who presented about her parking booth collaboration. At that time I was conducting social experiments on crowded city blocks_like walking a route with a $14 \mathrm{ft}$. mobility cane, and videotaping people as they jumped out of the way. After listening to Deborah's lecture I began to consider the work that I had been doing as a temporary service-and although I was not completely content with my strategy for engaging an audience / participant, I got excited by the idea that I, an artist, could create something useful for a community. Prior to moving to Portland for my MFA I had worked, for years, as a counseller and support worker for children and adults at the Canadian National Institute for the Blind (CNIB). I remember always feeling restricted by the parameters within which I was to provide support, and not always agreeing with the goals that the institution had me work toward with my clients. As I met individuals for which the institutional model was not a comfortable fit, I began to think of other possible contexts from which I could offer support. It wasn't until the summer of 2010, when I worked as 
the Arts programmer and coordinator for a camp for visually impaired youth on a small island off the coast of British Columbia, that I began to conceive of alternative models for education and social work. The camp was a utopia-an idyllic beachfront resort where deer ate apples from trees in the shade on balmy afternoons. As I facilitated craft-making activities with groups of young campers, and lead casual, impromptu conversations about their fears and their adjustment to vision loss, I thought to myself that the institutional approach to providing support was not as productive as a one-on-one, meaningful experience. I soon stopped working for the CNIB and began to develop creative projects that referred to an aspect of my disability experience, and which I felt achieved what my social work was achieving. From that point on my support work would take the shape of experiential non-object-based art projects that were educational and hopefully transformative for the audience / participant. This practice, of creative problem solving and innovative critique, has been the focus of my work for just over a year now, and, I feel, is at the heart of the work of Temporary Services. With projects such as Park, Midwest Side Story and the Half Letter Press (just to name a few) it is clear that Temporary Services is invested in promoting and problematizing accessibility. It is at this conceptual starting point that l'd like to open our conversation.

Sincerely, Carmen Papalia 


\section{CURRICULUM VITA}

NAME: Whitney E. B. Mashburn

ADDRESS: 12 Melrose St, \#2

Boston, MA 02116

DOB: $\quad$ Gadsden, Alabama - November 24, 1984

\section{EDUCATION}

\& TRAINING: $\quad$ B.A., Studio Art and History of Art

Vanderbilt University

2004-2007

M.A., Counselor Education: Rehabilitation Counseling University of Alabama

2009-2012

M.A., Art and Art History: Critical and Curatorial Studies University of Louisville

2014-2016

AWARDS: Cressman Scholarship, University of Louisville 2014-2016

Outstanding Student in Rehabilitation Counseling Award, UA 2012

Phi Beta Kappa, Vanderbilt University

2007

Cooley Award for top art history senior, Vanderbilt University 2007

American Association of Museums, 2015-present

Council on Rehabilitation Education, Certified Rehabilitation Counselor, 2012-present 